\title{
UN NUEVO ENFOQUE EN LA INVESTIGACIÓN DE LA DOCUMENTACIÓN ÁRABE GRANADINA ROMANCEADA (ILUSTRADO CON DOS TRADUCCIONES INÉDITAS DE BERNARDINO XARAFÍ, ESCRIBANO Y ROMANCEADOR DEL REINO DE GRANADA) ${ }^{1}$
}

\author{
MANUEL C. FERIA GARCÍA \\ Universidad de Granada \\ JUAN PABLO ARIAS TORRES \\ Universidad de Málaga
}

\section{Introducción}

\section{Consideraciones previas}

El objetivo de este trabajo es doble. Por una parte, pretendemos dar a conocer, de manera global, la obra traductora del árabe al español de los Xarafí, auténtica saga de romanceadores cuyas actuaciones se remontan cuando menos al siglo XIV, y muy en especial la de Ambrosio y Bernardino Xarafí, escribanos del rey y del número de la ciudad de Granada.

Por otra parte, y éste es nuestro objetivo fundamental, proponemos aquí un nuevo enfoque complementario en el estudio y aprovechamiento del amplio corpus de escrituras andalusíes romanceadas durante los siglos XV y XVI, toda vez que el mismo ha sido tratado hasta el momento únicamente en su calidad de conjunto documental

\footnotetext{
${ }^{1}$ Este trabajo no habría visto la luz sin la colaboración de Teresa Espejo, Profesora del Departamento de Pintura de la Universidad de Granada, y de Eva Martín, Directora del Archivo Histórico Provincial de Granada, que tuvieron la amabilidad de poner a nuestra disposición el legajo en el que se incluían los dos romanceamientos que ilustran este estudio. Asimismo queremos agradecer la ayuda y el asesoramiento que sobre el mismo nos ha brindado, con una generosidad sin límites, Bárbara Jiménez, técnica del citado archivo. También queremos expresar nuestra mayor gratitud a José E. López de Coca Castañer, cuyos imprescindibles trabajos - como no podía ser de otra manera- citamos a lo largo de este artículo, y que además tuvo la inestimable amabilidad de facilitarnos en comunicación personal referencias sobre algunos de los traductores de la Granada del XVI, así como a los evaluadores de la revista Al-Qantara, algunas de cuyas observaciones nos han sido de gran utilidad.
}

Al-Qanțara XXVI, 1 (2005) 191-247 
de interés para la historia de los últimos momentos del islam andalusí $\mathrm{y}$, sobre todo, del tránsito a la historia moderna de Andalucía, ignorando la naturaleza primaria de estos textos - que no son sino traducciones - o tomándola en consideración, en todo caso, como inconveniente. En síntesis, nuestra propuesta se funda en considerar que dicho patrimonio documental debe ser abordado también, y probablemente en primer lugar, en cuanto que parte fundamental de la historia de la traducción en España, y en especial de la historia de la traducción del árabe al castellano, y por consiguiente, en términos más amplios, en cuanto que parte de la historia del arabismo español. Si tomamos en consideración, por otra parte, el interés de estos textos y sus artífices para los estudios sobre mudéjares y moriscos, nuestra propuesta, en definitiva, no hace sino atender al llamamiento a la necesaria interdisciplinaridad en dicha área de investigación que ya hace más de una década hiciera Mercedes García-Arenal ${ }^{2}$.

Un análisis tal, como creemos queda demostrado en las páginas que siguen, resulta de interés tanto para historiadores del arabismo y la traducción como para los de la historia moderna de España. Para estos últimos, un análisis traductológico previo no puede sino repercutir en un abordamiento de los textos metodológicamente mejor fundamentado. De otro lado, viva la conciencia de que sus trabajos conforman una fuente única e inestimable para el arabista y el historiador de la traducción, las ediciones de este tipo de documentos y las investigaciones llevadas a cabo por los estudiosos de la historia moderna de España podrán ser objeto de nuevos y más completos cuidados.

Los dos nuevos romanceamientos de Bernardino Xarafí que aquí damos a conocer son, pues, sólo una excusa para poner en práctica este nuevo modo de abordar los romanceamientos de los siglos XV y XVI. Por tanto, no serán objeto de atención preferente los datos relativos a la historia local, topónimos o numerario que puedan aparecer en los textos editados, extremos en los que han centrado su atención estudiosos anteriores. Por el contrario, y siguiendo las propuestas lanzadas en los últimos años en áreas de investigación tales como la Tra-

2 García-Arenal, M., "El problema morisco: propuestas de discusión", Al-Qantara, II (1992), 491-503. Ya en Feria García, M. C., "Los moriscos y el uso de la aljamía", Al-Andalus-Magreb, 8-9 (2000-2001), 2, 299-323, tratábamos de atender a ese llamamiento en base a criterios traductológicos y, también en aquel caso, sociológicos y antropológicos. 
ductología Descriptiva ${ }^{3}$ o la Historia de la Traducción ${ }^{4}$, resaltaremos la figura del romanceador en su contexto familiar, religioso y administrativo ${ }^{5}$, así como ofreceremos un análisis traductológico de los textos editados: características definitorias, patrones de traducción y evolución ideológica o formal en relación a otras traducciones de su misma naturaleza anteriores y posteriores a las aquí editadas -incluidas traducciones actuales - y otros extremos de interés desde el punto de vista de la traductología.

\section{Un expediente del siglo XVI llama la atención}

Gracias a los trabajos de catalogación que el Archivo Histórico Provincial de Granada está llevando a cabo de manera progresiva y, sobre todo, a raíz de la reorganización de sus fondos con motivo del reciente traslado a su nueva sede, han salido a la luz una serie de documentos que, por su gran interés, han sido restaurados para garantizar su correcta conservación ${ }^{6}$. Entre los documentos seleccionados se haya un expediente, número currens 5276-5, perteneciente al copioso fondo del Fisco de la Inquisición, que llamó la atención de la Dirección de este Archivo, además de por su deplorable estado - que hacía necesaria una intervención urgente-, por presentar cosidos dos manuscritos en lengua árabe.

\footnotetext{
3 Véase, por ejemplo, Peña, S., "El traductor en su jaula: hacia una pauta de análisis de traducciones", en El papel del traductor, Morillas, E. y Arias, J. P. (eds.), Salamanca, Colegio de España, 1997.

${ }_{4}^{4}$ Por ejemplo por Delisle, J. y Woodsworth, J. (eds.), Translators through History, Presses de l'Université d'Ottawa, 1995 o Delisle, J. (dir.), Portraits de traducteurs, Presses de l'Université d'Ottawa, 1998.

${ }_{5}$ Cuando el traductor es al tiempo escribano público, como es el caso que aquí nos ocupa, insistiremos en su primera faceta. De hecho, las escribanías andaluzas en el tránsito de la Edad Media a la Moderna están siendo en los últimos años objeto de atención entre los investigadores, aunque se ha dejado prácticamente en la incuria sus relaciones con la historia de la traducción. A modo de ejemplo, véase Ostos Salcedo, P. y Pardo Rodríguez, M. ${ }^{a}$ L. (eds.), El notariado andaluz en el tránsito de la Edad Media a la Edad Moderna, Sevilla, 1995; Pardo Rodríguez, M. ${ }^{a}$ L., Señores y escribanos. El notariado andaluz entre los siglos XIV y XVI, Sevilla, Universidad, 2002, y Merchant Rivera, A., Los escribanos públicos en Málaga bajo el reinado de Carlos I, Málaga, SPICUM, 2002.

${ }^{6}$ Esta restauración ha sido realizada mediante un contrato de investigación que bajo el título "Asesoramiento, investigación e intervención en conservación y restauración de documento gráfico y material de archivo», y gestionado a través de la Fundación Empresa-Universidad de Granada, dirige la citada T. Espejo.
} 
El legajo está compuesto por cuarenta y dos folios, de los cuales cuarenta son en papel (del 1 al 17 y del 19bis al 41) y corresponden al expediente en castellano. Están redactados en letra procesal, aunque con algunas muestras de itálica. Los folios 18 y 19 los ocupan dos pergaminos en lengua árabe. La foliación a lápiz que presenta corresponde a una intervención restauradora anterior a la realizada por la Universidad de Granada en la que el documento fue desmontado y los manuscritos sobre pergamino separados del conjunto ${ }^{7}$.

Contiene dicho legado el expediente ejecutivo final de fecha 31 de julio de 1551 relativo al pleito interpuesto ante el Juez de Bienes Confiscados, Luis de Messía, por Rodrigo Zazo (Çaço), Receptor del Santo Oficio de los Bienes Confiscados, contra Diego López Portillo, Receptor del número de la Audiencia Real. El objeto de la demanda son doscientos veintisiete ducados y medio de oro que corresponden a la mitad de las casas de los hijos de Juan Pérez, platero: Francisco, María, Isabel y Lorenzo, todos ellos cristianos nuevos de judío, condenados por herejía por el Santo Oficio y ejecutados el 27 de mayo de 1539. Rodrigo Zazo pide, además de la devolución de la citada cantidad, los intereses devengados así como los frutos y rentas que haya producido la mitad de las dichas casas ${ }^{8}$.

Este pleito es continuación de otro anterior, de fecha 19 de octubre de 1542 (f. ${ }^{\circ} 10$ ), en el que Diego López de Portillo fue condenado a entregar al Fisco de la Inquisición la parte correspondiente a la mitad de las casas propiedad de Juan Pérez, declarado hereje años atrás y cuyos bienes fueron confiscados. El 22 de junio de 1554 (f. ${ }^{\circ} 35$ a y 35 r) se emite sentencia definitiva por un nuevo juez, el Licenciado Benito de Gamboa, en la que se condena a Diego López de Portillo a pagar a Rodrigo Zazo la cantidad demandada ${ }^{9}$.

\footnotetext{
7 Tanto estos datos como otros que aparecerán a lo largo del presente trabajo sobre el estado de conservación y proceso de restauración de este legajo han sido comunicados personalmente por T. Espejo a los autores.

${ }_{8}$ Respecto al funcionamiento del fisco de la Inquisición, ingresos y penurias económicas durante la etapa coetánea a este proceso y su posterior reorganización bajo la batuta del inquisidor Valdés, véase el excelente trabajo de Martínez Millán, J., La Hacienda de la Inquisición (1478-1700), Madrid, 1984

9 Según García Ivars, F., La represión en el tribunal inquisitorial de Granada (1550-1819), Madrid, 1991, en esta ciudad fue constante el pulso de poder mantenido entre el Santo Oficio y la Chancillería, con clara victoria del primero, como queda reflejado en la notable cifra de pleitos iniciados por el tribunal inquisitorial contra miembros o familiares de la hacienda real. De otro lado, según comunicación personal de la citada $\mathrm{B}$.
} 
En el folio 1r se alude a la documentación aportada en este proceso y que se conserva en el expediente citado:

1) Actas notariales, copias testimoniadas de los autos originales, de las condenaciones de Francisco, María e Isabel Pérez (Folios 16a, 16r 17 a y $17 \mathrm{r})^{10}$. Estas actas están firmadas por el notario del Santo Oficio Pedro de Torquemada. En el proceso intervinieron los inquisidores Dr. Arias y Licenciado Montoya ${ }^{11}$, así como el Dr. Ortiz, provisor y juez ordinario de la ciudad de Granada y su Arzobispado.

2) Certificado de Depósito de los dineros entregados por Rodrigo Zazo a Diego López de Portillo en fecha anterior, de acuerdo con la sentencia del primer pleito habido entre ambos.

3) Carta de compraventa de los inmuebles en litigio, con los manuscritos de los títulos de propiedad originales en árabe y sus correspondientes romanceamientos, documentos que han dado lugar a este trabajo.

\section{Los romanceamientos granadinos editados. Estado de la cuestión}

\section{Romanceamientos editados. Las ediciones y sus prioridades}

El interés por los romanceamientos granadinos como rica fuente documental para el estudio de la Granada islámica viene de largo. La primera edición que nos consta de una de estas traducciones del árabe data de finales del siglo XIX y la debemos a Garrido Atienza ${ }^{12}$. Se trata del romanceamiento de un acta de testimonio redactada en el siglo XII y tocante al reparto de aguas del río Genil en Granada firmado por Miçer Ambrosio Xarafí ${ }^{13}$ el 12 de febrero de 1502.

Jiménez, y a la luz de nueva documentación en proceso de clasificación, el pleito no terminó aquí, pues Aldonza Álvarez de Herrera, viuda de Diego López, e hijos apelaron ante el Consejo de la Inquisición en Valladolid.

${ }_{10}^{10}$ No aparece, sin embargo, la fe de condenación de Lorenzo.

11 Sobre este inquisidor, muerto en 1550, y otros personajes vinculados en esta época al Santo Oficio puede verse Gan Jiménez, P., "Los prebendados de la Iglesia granadina", Revista del Centro de Estudios Históricos de Granada y su Reino, 4 (1990), 149-212.

${ }_{12}$ Garrido Atienza, M., Los Alquézares de Santafé, Granada, 1893 (edición facsímil, Granada, 1990).

${ }_{13}$ Sobre este romanceador y otros que irán apareciendo en este apartado, véanse las secciones 5 y 6 de este trabajo. 
Hasta bien entrado el siglo XX, que sepamos, no vuelven a ver la luz ediciones de este tipo. Concretamente, entre los años cuarenta y setenta de dicho siglo recogen el testigo de esta labor Seco de Lucena ${ }^{14}$, editor de tres documentos árabes con sus respectivos romanceamientos firmados por Juan Rodríguez; Bejarano ${ }^{15}$, quien hace lo propio con un acta notarial traducida por un alfaquí anónimo malagueño; y, finalmente, López de Coca ${ }^{16}$, que edita una escritura romanceada el 15 de abril de 1496 por el "alfaquí Xarafi», cuyo original había sido levantado en el año 724 de la hégira.

$\mathrm{El}$ interés por este tipo de documentos renace en los años ochenta y desde entonces no ha hecho sino aumentar gracias a la intervención decidida de una nómina bien nutrida de investigadores - muchos de ellos vinculados a la Universidad de Granada - entre los que cabe señalar a los profesores Espinar, Santiago, Osorio, Malpica, Trillo, Peinado, Álvarez de Morales, Martínez Ruiz o Albarracín, entre otros ${ }^{17}$. A ojo de buen cubero, disponemos pues de la edición de más de dos centenares de textos traducidos desde mediados del XV hasta finales del siglo XVI, concretamente entre los años $1494{ }^{18}$ y $1593{ }^{19}$, correspondientes a originales de los siglos XII al XVI.

${ }^{14}$ Seco de Lucena, L., "Documentos árabes granadinos. I. Documentos del Colegio de Niñas Nobles", Al-Andalus, 8 (1943), 415-29.

15 Bejarano, F., Documentos del Reinado de los Reyes Católicos. Catálogo de los documentos existentes en el Archivo Municipal de Málaga, Madrid, 1961, 596, doc. 94.

${ }^{16}$ López de Coca Castañer, J. E., La tierra de Málaga a fines del siglo XV, Granada, 1977, 596-7, doc. n. 95.

17 Una bibliografia sobre documentos granadinos (tanto originales como romanceados) puede consultarse en los trabajos de Viguera, M. J., "Historiografia: fuentes documentales", Historia de España Menéndez Pidal. VIII.3 El Reino Nazari de Granada. Política, instituciones, espacio y economia, 34-7, Madrid, 2000, y "Sobre documentos árabes granadinos", En el epílogo del islam andalusi: La Granada del siglo XV, C. del Moral (ed.), 117-38, Granada, 2001, que hemos tomado, junto a Feria García, M. C., La traducción fehaciente del árabe: fundamentos históricos, jurídicos y metodológicos, Tesis Doctoral inédita dirigida por S. Peña, Universidad de Málaga, 2001, como punto de partida para este trabajo. Esta lista ha sido completada y actualizada, especialmente en el apartado de romanceamientos, como podrá comprobarse en la bibliografia citada en las páginas que siguen. Además pueden verse una descripción y clasificación de la misma para futuras explotaciones en Arias Torres, J. P. y Feria García, M. C., "Documentos árabes romanceados: una mina a cielo abierto para la historia de la traducción y la traductología", Trans, 8 (2004), 179-184.

18 Mesa Soria, E., "La venta de bienes de la casa Real. El caso de Gor bajo Muhammad IX el Izquierdo", Miscelánea de Estudios Árabes y Hebraicos, $42-43$ (1993-94), 291-304.

19 Espinar Moreno, M., "De la mezquita de Maharoch al monasterio de San Jerónimo. Noticias para el urbanismo y la arqueología de Granada (1358-1505)", Cuadernos de Estudios Medievales, 18-19 (1994), 73-97. 
Empero, antes de seguir adelante, quisiéramos hacer una breve reflexión respecto a los objetivos y prioridades de estas ediciones. Adelantábamos que, pese al esfuerzo realizado hasta el momento, en ningún caso la edición responde a un interés, siquiera secundario, por la historia de la traducción del árabe al castellano ${ }^{20} \mathrm{o}$ atiende a la naturaleza primaria de los textos, lo que conduce en ocasiones a extrañas paradojas.

Para Osorio ${ }^{21}$, por ejemplo, «las heredades, pagos, tierras incluidos en ellos [en los documentos romanceados que regesta] son numerosísimos y sin duda pueden aportar algún fundamento a los estudios antroponímicos y toponímicos que se están realizando». Esto explica que en el trabajo citado incluya un índice de nombres de lugar y de personas, pero únicamente afirme del traductor y su obra lo que sigue: «Todas ellas fueron traducidas por Juan Rodríguez, escribano el cual al no ser buen romanceador, deja numerosos espacios en blanco, sobre todo los referentes a los nombres de personas o lugares» ${ }^{22}$. De entrada, esta afirmación sobre la impericia traductora de Juan Rodríguez contrasta notablemente con lo expresado en la primera cita de la misma autora ${ }^{23}$. Realmente el fenómeno de los espacios en blanco es digno de tenerse en cuenta y exige explicación, en mayor medida aún cuando el pretendido provecho del corpus radica en los topónimos y antropónimos, que es justamente donde aparecen más espacios en blanco. Empero, la ex-

${ }^{20}$ Esto no quiere decir que, en algunos casos, como Espinar Moreno, M., "Escrituras árabes inéditas del siglo XV romanceadas por Alonso del Castillo", Miscelánea de Estudios Árabes y Hebraicos, 46 (1997), 29-48, el editor no haya intuido el interés de ciertas noticias que, pese a escapar al asunto que le ocupa, son proporcionadas igualmente. De todas formas, da la impresión de que, incluso en el trabajo citado, Espinar considera esta información desde el punto de vista de su interés para la historia del derecho español, y no realmente para la historia de la traducción del árabe al castellano.

21 Osorio Pérez, M. J., "Regesta de documentos granadinos romanceados del Archivo del Colegio de San Bartolomé y Santiago de Granada", Cuadernos de Estudios Medievales, 12-13 (1984), 128.

22 Ibidem. Otro curioso comentario sobre la supuesta impericia o traducción «algo liberal» de un traductor mudéjar puede leerse en Acién Almansa, M., "Dos textos mudéjares", Cuadernos de Estudios Medievales, 2-3 (1974-5), 245-57, lo que justifica que este investigador ofrezca su propia traducción de los originales.

${ }_{23} \mathrm{De}$ hecho, Osorio es la única investigadora que pone en tela de juicio la capacidad de Juan Rodríguez como romanceador. Frente a ella, Seco de Lucena, al editar los textos árabes del Colegio de Niñas Nobles de Granada, se limita a presentar los traslados de Juan Rodríguez por no haber hallado en ellos motivo de tacha. Más adelante tendremos también ocasión de comprobar el respeto que Juan Rodríguez, como romanceador, inspiraba a un autor de la talla de Juan Martínez Ruiz. 
plicación que ofrece la citada profesora parece - con todos nuestros respetos - demasiado simple. De hecho, el mismo Juan Rodríguez, como era de esperar, lo explica en diversas ocasiones. Así, afirma en otro romanceamiento que «los que lo corrigieron con su original e los hallaron conformes eçebto algunas partes que en el original se avian despintado e quedan aqui en blanco segund sera dicho»' ${ }^{24}$. Y en una de las «cartas bermejas» romanceadas por él en Calahorra, concretamente la fechada el 30 de julio de 1551, afirma en la leyenda del traductor: «Tres partes que van de blanco no se pudieron traduxir porque estava el papel rasgado» ${ }^{25}$. Como decíamos, ignorar la naturaleza primaria de estos textos conduce a extrañas paradojas.

La edición y el recurso a textos romanceados —esto es, «no originales»- exige, por tanto, justificaciones. Osorio y Santiago añaden algunas otras a las antes señaladas por Osorio: primero, el «copioso número de nombres de lugar - mayores y menores-, algunos sin registrar aún, cuyo interés podrá ser apreciado por los estudiosos del tema»; segundo, las noticias que nos ofrecen los documentos desde un punto de vista numismático y, tercero, porque algunas de estas traducciones reflejan originales «de fechas incluso anteriores en muchos años a las publicadas por el Prof. Seco de Lucena» ${ }^{26}$. Insistimos: puesto que las razones que mueven a publicar estos documentos son exclusivamente del carácter descrito, es comprensible que el hecho de que sean traducciones constituya en realidad un inconveniente, aunque la mayor parte de las fuentes secundarias eviten la cuestión. Los dos editores que acabamos de citar, sin embargo, son plenamente conscientes de ello, como puede deducirse del tono justificativo de las siguientes palabras ${ }^{27}$ :

La fidelidad que existiera entre los textos que damos a conocer y sus respectivos originales árabes, hoy perdidos, debió ser en extremo rigurosa — por más que

${ }^{24}$ Editado por Espinar Moreno, M., "El reparto de las aguas del río Alhama de Guadix en el siglo XII (año 1139)", Estudios sobre Málaga y el Reino de Granada en el V centenario de la conquista, J. E. López de Coca Castañer (ed.), Málaga, 1987, 252.

${ }^{25}$ Grima Cervantes, J. y Espinar Moreno, M., "Estudio de algunas cartas de los reyes nazaríes dirigidas a los habitantes de Huércal", Revista del Centro de Estudios Históricos de Granada y su Reino, 2 (1988), 39-57.

${ }^{26}$ Osorio Pérez, M. J. y Santiago, E. de, Documentos arábigo-granadinos romanceados, Granada, 1986, IV. Aluden a Seco de Lucena, L., Documentos arábigo-granadinos, edición crítica y traducción, Madrid, 1961.

27 Osorio y Santiago, Documentos, II-III. 
cupiera pensar en la hipótesis de proteicas alteraciones e inexactitudes, efectuadas al momento de su romanceado por los escribanos bilingües-, pues apenas difieren, en su estructural esencial, de documentos análogos arábigo-granadinos del repertorio antes aludido, publicado por Seco de Lucena.

¿Por qué la hipótesis de las alteraciones e inexactitudes — que por cierto no es ninguna hipótesis, por más que pese- habría de ser «proteica»? ¿Quién es Juan Rodríguez y qué otros romanceamientos suyos demuestran que esa hipótesis es proteica? De hecho, tampoco a estos autores parece interesarles la identidad de los «escribanos bilingües» - ¿en plural? - y, no sólo no tratan de recabar dato alguno sobre él - ¿o ellos? - , sino que ni siquiera consideran necesario disculpar el no haberlo encontrado ${ }^{28}$. ¿Cómo puede explicarse esta nueva paradoja? Basta, pues, con presuponer que los romanceadores son buenos o malos, según convenga.

Un año más tarde, Santiago ${ }^{29}$ añade un nuevo argumento a favor de la edición de estos documentos:

\begin{abstract}
Es evidente que el interés que ofrecen estos textos deriva de su propia entidad, en tanto que fuentes informativas para el estudio del fiqh o derecho islámico y cómo no, también para el estudio del derecho comparado. Las fórmulas estereotipadas que se recogían en los prontuarios notariales tradicionales, evolucionaron en el tiempo, hasta concluir en modalidades como las consignadas a continuación, testimonios vivos de la natural intervención de particulares usos y costumbres de la práctica judicial, dentro de las coordenadas de especiales circunstancias de lugar y tiempo.
\end{abstract}

Resulta curioso que el interés de estos textos radique precisamente «en su propia entidad» y que la razón de ello sea que reflejan una evolución en las prácticas notariales de sus originales perdidos. Debemos suponer, por consiguiente, que el romanceamiento en sí no existe ni nunca tuvo entidad ni función alguna; que el trabajo de llevarlo a cabo fue absolutamente gratuito; que no cabe pensar en una evolución en los usos de los romanceadores y, en resumidas cuentas, parafraseando a nuestro querido profesor Emilio de Santiago, que «no hay vida fuera del arabismo» ${ }^{30}$.

${ }^{28}$ Se trata del mismo modo de proceder seguido antes por González Palencia, A., "Documentos árabes del Cenete", Al-Andalus, 5 (1940), 301-82.

${ }_{29}$ Santiago Simón, E. de, "Algunos documentos arábigo-granadinos romanceados del Archivo Municipal de Granada", Revista del Centro de Estudios Históricos de Granada y su Reino, 1 (1987), 261-269.

30 Aunque se centra en la edición de textos aljamiados y reflexiona desde una perspectiva histórica, y no propiamente traductológica, García Pedraza, A., Actitudes ante la 
Aunque, en fin, sería injusto atribuir la tacha al arabismo. Trillo ${ }^{31}$, por ejemplo, sólo ve en la documentación árabe romanceada un conjunto de textos históricos de primer orden, ya que «la documentación referida a la Alpujarra, especialmente en fechas tan próximas a la conquista cristiana, es bastante exigua». Afirmaciones de este corte, perfectamente generalizables a todos los romanceamientos de la época, explican que en muchos casos incluso se haya suprimido de la edición la leyenda del traductor, únicamente se haya conservado en nota marginal o se haya desgajado de los romanceamientos quebrando por completo la unidad textual de estas fuentes, proceder común, por ejemplo, en los trabajos de Espinar Moreno. Si la información ha de proceder inevitablemente de fuentes tales, mejor será olvidarnos de que no tratamos con «originales» o considerar este hecho un «accidente» de la historia. Hasta hoy, en definitiva, a nadie le ha interesado subrayar la existencia de una labor previa de traducción en sus fuentes; si acaso, como vemos, se alude a ello de soslayo y con tono justificativo.

Por otra parte, el interés por el romanceador — cuando existepudiera interpretarse como un primer indicio de consideración hacia «la propia entidad» de los textos editados. Pero lo cierto es que esto no es necesariamente así. A modo de ejemplo, en el abstract del trabajo de Espinar Moreno antes citado ${ }^{32}$, el editor afirma que los documentos en cuestión permiten conocer «aspectos inéditos de la ciudad de Granada en época musulmana, toponimia, vivienda, calles, costumbres sobre el abastecimiento de aguas, acequias, familias, precios, dinero, etc.»; y además, afirma, «damos a conocer documentos traducidos por este romanceador hasta ahora desconocidos por los estudiosos de este personaje granadino». No obstante, el interés por Alonso del Castillo ${ }^{33}$ refleja en realidad el vivo interés de la erudición espa-

muerte en la Granada del siglo XVI. Los moriscos que quisieron salvarse, Granada, Universidad, 2002, t. 1, 75 y ss., subraya también esta estrechez de miras de buena parte del arabismo español (sin perjuicio de sus muchas y muy valiosas aportaciones).

31 Trillo San José, C., "Dos cartas árabes romanceadas del Archivo de La Alhambra", Cuadernos de La Alhambra, 28 (1992), 271.

32 "Escrituras árabes inéditas del siglo XV". Obsérvese, por cierto, el título de este trabajo: "Escrituras árabes inéditas del siglo XV romanceadas por Alonso del Castillo". ¿Escrituras árabes inéditas o romanceamientos inéditos?

${ }^{33}$ Respecto a Alonso del Castillo, aparte de los romanceamientos editados, véase principalmente Cabanelas, D., El morisco granadino Alonso del Castillo, Granada, 1965, y Corriente, F. y Bouzineb, H., Recopilación de refranes andalusies de Alonso del Castillo, Zaragoza, 1994. 
ñola por la epigrafía árabe y el estudio de los moriscos ${ }^{34}$, e incluso, concretando un poco más, por los moriscos o mudéjares más predispuestos a la colaboración con las autoridades castellanas, que no directamente por la figura de Alonso como traductor e intermediador fundamental entre los dos grupos sociales mayoritarios de la convulsa y apasionante Granada de la época. De hecho, cuando Espinar edita actas romanceadas por otros traductores no considera la importancia de los mismos, no ya desde el punto de vista de los estudios de traducción, lo que sería comprensible, sino ni siquiera desde un punto de vista puramente histórico, cuando lo cierto es que «es imprescindible adentrarse en el perfil sociológico de los intérpretes, intermediarios fundamentales sin los que nunca estará completo cualquier intento que se haga de acercarse a la convivencia de ambas comunidades [cristiano viejos y cristiano nuevos] ${ }^{35}$.

En cualquier caso, es indudable que la labor inestimable realizada hasta hoy por los editores de romanceamientos granadinos, aun cuando tenga fines lingüísticos, sociohistóricos, jurídicos, económicos, numismáticos, toponímicos o urbanísticos, y no propiamente traductológicos, nos permite hacernos una idea del modo en que se traducían los instrumentos notariales árabes en la España de principios de la Edad Moderna, así como de las circunstancias que rodeaban a este tipo de traducciones y a sus artífices. A esos fines pretendemos ahora sumar nosotros el interés traductológico, toda vez que dichos textos son, por su propia naturaleza y por definición, documentos para la historia de la traducción.

Desde la perspectiva de los estudios de traducción, paradójicamente, ha sido una suerte que la conservación de la documentación árabe original - salvo excepciones - no tuviera significado para el nuevo poder establecido y fuera mandada traducir e -incluso- destruir; en caso contrario, apenas dispondríamos hoy de un romanceamiento editado.

${ }^{34}$ Puede verse un lúcido análisis de la evolución de este interés y sus razones en el notabilísimo trabajo de García Pedraza, Actitudes ante la muerte, t. 1, 25-100.

${ }^{35}$ La afirmación es de García Pedraza, Actitudes ante la muerte, t. 1, 463, n. 42. De hecho, García Pedraza constituye un ejemplo único del que debiera ser lógico interés de los historiadores por estas figuras. Véase la obra citada, t. 1, 457 y ss. 


\section{Descripción y contenidos de los romanceamientos objeto de estudio}

\section{Descripción fisica}

Tal y como adelantábamos, el anverso y reverso de los folios 19 bis y 20 del expediente objeto de estudio están ocupados por dos romanceamientos de las que parecen ser escrituras de propiedad de los inmuebles objeto del litigio en cuestión. Como buena parte del expediente, el estado de conservación de ambos traslados es muy deficiente. Originalmente se encontraban cosidos al resto del expediente por la zona de la cabecera y parcialmente doblados para adaptarlos al formato de las hojas. Presentaban signos evidentes de haber estado sometidos a unos elevados índices de humedad que habían solubilizado las tintas, lo que provoca que en determinados puntos la lectura del texto sea muy difícil. Además, su conservación en condiciones de temperatura elevadas ha favorecido la acción de microorganismos testimoniada en un soporte casi inmanipulable, numerosas lagunas y un cromatismo característico.

\section{Contenidos}

De fecha 30 de diciembre de 1517, ambos romanceamientos van firmados por Bernardino Xarafí, actuando como testigos del traslado Ínigo Xarafí, Lorenzo de Mora y Juan López de Zardos (?). Según el primero de estos documentos (f. ${ }^{\circ} 19$ bis a y r), el citado Juan Pérez, platero, compra a Fátima hija de Hamete el Marini ${ }^{36}$ una casa en el barrio de Bibataubín por dieciséis pesantes de plata el 13 de safar del año 905 de la hégira (19 de septiembre de 1499). En el segundo traslado (f. 20 a y r), Juan Pérez, apenas un mes después (11 de rabi I $905=16$ de octubre de 1499), adquiere de Mahomad hijo de Mahamad Abiz una casa en el citado barrio de Bibataubín, muy posiblemente contigua o próxima a la anterior, de acuerdo con las lindes citadas en ambos traslados.

${ }^{36}$ Curiosamente la calle del Marini aparece citada entre las vías del barrio de Bibataubín en, por ejemplo, Seco de Lucena, L., Documentos arábigo-granadinos. 
En el expediente (f. ${ }^{\circ}$ 23) encontramos algunos breves datos complementarios sobre estas propiedades:

\footnotetext{
[...] unas casas e almacerías que son en esta ciudad de Granada en la collacion de Santo Mathias que alindan con casas que fueron de Garcia de Vaena y con casas de Pedro de Ocaña, mercaderes, e otros linderos sobre que es este pleito.
}

Asimismo sabemos que dichas propiedades fueron vendidas en 1527 por Juan Pérez y sus hijos a Juan de Andújar, mercader, y a Teresa de Molina, su mujer, vecinos de Granada ${ }^{37}$.

\section{Relación entre los romanceamientos y los instrumentos notariales en lengua árabe contenidos en el expediente}

El primer romanceamiento (f. ${ }^{\circ} 19$ bis) llevaba originalmente cosidos los dos pergaminos (f. ${ }^{\circ} 18$ y f. $^{\circ} 19$ ) por la cabecera, quedando perpendiculares al resto del expediente. Tras el proceso de restauración, los documentos árabes han sido colocados en carpeta de poliéster al final del documento.

Lamentablemente, la relación entre ambos romanceamientos y los títulos en árabe es nula, al menos para el primero de los dos manuscritos. El acta de compraventa que contiene el manuscrito 1 (f. ${ }^{\circ} 18$ ) se refiere a un predio en la localidad de Armilla, cercana a Granada, y por lo tanto no guarda conexión con los inmuebles que venimos describiendo. Además, esta acta está fechada el 23 de safar de $871(=4$ de octubre de 1466). Tampoco existe coincidencia alguna con los comparecientes en dicha compraventa.

De la segunda acta, segundo pergamino en árabe (f. $\left.{ }^{\circ} 19\right)$, tampoco podemos señalar a ciencia cierta qué relación guarda con los romanceamientos, pues su lamentable estado de conservación hace imposible su correcta interpretación. En la parte superior, mejor conservada y más legible, se reproduce básicamente el poder que la vendedora, Umm al-Fath, otorga a su hermano para actuar en su nombre y derecho en la venta de un solar y vivienda que ambos poseen en régimen de propiedad indivisa dentro de las lindes de la ciudad de Granada.

${ }^{37}$ Por dos nuevos fragmentos de este expediente recién hallados (ver nota 6), sabemos que este Juan de Andújar vendió la casa, un palacio morisco a la espaldas del Monasterio de la Encarnación, al citado Diego López de Portillo. 
De igual modo las fechas que se alcanzan a leer al principio y final de este documento ( 7 de safar de $877=14$ de julio de 1472 y 10 de $d u l$ qaeda de $877=8$ de abril de 1473) distan bastante de las reflejadas en los romanceamientos. En cualquier caso, sí parece que el cuerpo central del manuscrito está conformado por un acta de compraventa de propiedades inmuebles en la ciudad de Granada ${ }^{38}$.

Por último, quedaría por explicar por qué o cómo llegaron esas actas en árabe, y en especial la primera, aparentemente inconexa con el pleito, a este legajo. Acaso la aparición de la primera parte de este expediente ejecutivo en la futura y deseable reordenación de los Fondos del Fisco de la Inquisición obrantes en poder del Archivo Histórico Provincial de Granada pueda arrojar alguna luz a este respecto. Todo lo demás es campo abierto a la mera conjetura.

\section{Edición de los romanceamientos}

\section{Documento $1^{39}$}

Archivo Histórico Provincial de Granada

Legajo 5276-5, F. ${ }^{\circ} 19 \mathrm{bis}$ a - r

Año 1499 (13 de safar de 905)

Escritura por la que Fátima hija de Hamete el Marini vende al cristiano Juan Pérez una casa en el barrio de Bibataubín, en la ciudad de Granada, en precio de dieciséis pesantes de plata.

Traslado del original árabe, por Bernardino Xarafí, 30 de diciembre de 1517. Papel, escritura procesal.

Inserto en el pleito ante el Juez de Bienes Confiscados de Granada entre Rodrigo Zazo y Diego López de Portillo, por la mitad de las casas de Juan Pérez e hijos.

Este es [traslado] bien e fielmente sacado de una carta de [vendida] de arávigo original escrito en $\mathrm{p}$ [apel] en letra aráviga e firmada de dos alfaquíes [escriva]nos

${ }^{38}$ Esperamos en un futuro próximo ofrecer la edición completa, estudio y traducción del primero y una reconstrucción parcial del segundo.

${ }^{39}$ Los fragmentos reconstruidos, no legibles en el original, están indicados mediante corchetes. Para la transcripción de ambos traslados hemos seguido los usos y normas de los investigadores citados, sin adaptar la versión a la ortografía actual del español, aunque incluyendo algunas tildes para una mejor comprensión. 
públicos e segund por ella paresçia su [tenor] de la qual tornada en lengua catellana $\mathrm{d}$ [ize en] esta guysa:

Los loores a Dios. Vendio la [onrada] Fatima fija de Hamete el Marini al cristiano [Juan Pérez], platero, toda la casa que es en el barrio de la p[uerta de Bi]bataubin dentro de Granada, que alinda por la $p$ [arte] solana con el Carmoni e por la parte del çierç[o con ] el Arbi e por la parte del levante con el Carmon[i e] por la parte del poniente con Abengalib, con s[us] derechos e devedamientos e con todas sus pertenencias, vendida cunplida por presçio e contia de diez e seis pesantes de plata de los de a diez dineros nuevos que los resçibió la vendedora e pasaron a su mano e le dio por quito finequito cunplido e por ello cunplió al comprador el señorío de la casa susodicha en[tera e cumplida]mente por la regla e çuna de mor[os e se obligó de s]aneamiento despues que la vieron e [reconosçieron] e fueron contentos e supieron lo [que fazi]an e asi lo otorgaron ante quien los con[osçieron] con salud y es bastante. Fecha a treze dias de [la luna de Çafar] año de novecientos e cinco años [e la fir]maron de sus nombres dos alfaquíes escri[vanos p]úblicos.

Concuerda la fecha de la carta de arávigo original susodicha con el año del nasçimiento de nuestro Salvador Thesuchristo de mil e quatrocientos e noventa e nueve años.

Fecho e sacado fue este dicho traslado de la dicha carta de vendida de arávigo original en la muy noble nonbrada e grand çibdad de Granada a treinta días del mes de diziembre año del nasçimiento de nuestro Salvador Ihesu

Va sobreraydo o diz barrio de la puerta. Vala.(Rúbrica)

\section{[19bis r]}

christo de mil e quinientos [e diez] e siete años. Testigos que fueron presentes al leer [e c]onçertar este dicho traslado con la dicha carta de vendi[da de ará]vigo original Yñigo Xarafí e Lorenço [de Mora] e Juan López de [Çardos/Descudos(?)] vecinos de esta dicha çibdad de Granada. E yo Bernaldino Xarafi escrivano de la Rey[na e] del Rey su fijo nuestros señores, escrivano público de [numero] de la dicha çibdad de Granada e su tierra presente [fui en] uno con los dichos testigos a leer e conçertar este dicho traslado con la dicha carta de vendida de arávigo original la qual señalé e romançé e esto fize escrivir e por ende fize aqui este myo signo (rúbrica) en testimonio de verdad.

Bno Xarafi. Escrivano público.

\section{Documento 2}

\section{Archivo Histórico Provincial de Granada}

Legajo 5276-5, f. 20 a - r

Año 1499 (11 de rabi I de 905) 
Escritura por la que Mahomad hijo de Mahamad Abiz vende al cristiano Juan Pérez una casa en el barrio de Bibataubín, en la ciudad de Granada, en precio de cuarenta pesantes de plata.

Traslado del original árabe, por Bernardino Xarafí, 30 de diciembre de 1517. Papel, escritura procesal.

Inserto en el pleito ante el Juez de Bienes Confiscados de Granada entre Rodrigo Zazo y Diego López de Portillo, por la mitad de las casas de Juan Pérez e hijos.

Este es traslado bien e fielmente sacado de una carta de vendida escrita en papel en letra aráviga firmada de dos alfaquíes escrivanos públicos segund por ella paresçia la qual tornada en [leng]ua castellana dize en esta guysa:

Los loores a Dios. Vendio Mahomad [hijo] de Mahamad Abiz al cristiano Juan Pérez toda la casa [que es] en Bibataubin dentro de Granada, que alinda por la par[te] solana con Abengalib e por la parte del çierço con la call[e e p]or la parte del levante con el Dobuz e por la parte [del p]oniente con el conprador suso dicho, con sus derech[os e] devedamientos e entradas e salidas venta conpl[ida p]or presçio e contia de quarenta pesantes de pla[ta de los] de a diez dineros que los resçibió el vendedor junt[amen]te e pasaron a su mano e poder e le dio por [quito dellos] finequito cunplido e por ello cunplió al con[prador] suso dicho el señorío de la dicha casa entera e cun[plida]mente por la regla e çuna de moros e se obli[gó de sane]amiento despues que la vieron e reconocieron [e fueron co]ntentos e supieron lo que fazian e asi lo [otorgar]on [a]nte quien los conosçió con salud e es bastante. [Fec]ha a honze dias de la luna de Rebealula año de nove[cient]os e cinco años e asi la firmaron de sus nombres d[os alf]aquíes escrivanos públicos.

Concuerda la fecha de la escritura de vendida en arávigo original suso dicha con el año del nasçimiento de nuestro Salvador Ihesuchristo de mil e quatrocientos e noventa e nueve años.

Fecho e sacado fue este dicho traslado de la dicha carta de vendida de arávigo original en la muy noble nonbrada grand çibdad de Granada a treinta días del mes de diziembre año del nasçimiento de nuestro Salvador Ihesuchristo de mil e quinientos e diez e siete años. Testigos que fueron presentes al leer e conçertar este dicho traslado con la dicha carta de vendida de arávigo original Yñigo Xarafí

[20r]

e Lorenço de Mora e [Juan López] de Çardos/Descudos (?) vezinos desta dicha çibdad d[e Grana]da. E yo Bernaldino Xarafi escribano de la Rey[na e del Re]y su fijo nuestros señores, escrivano público del [número de] dicha çibdad de Granada e su tierra presente [fui en] uno con los dichos testigos al leer e [conçertar] este dicho traslado con la dicha carta [de ven]dida de arávigo original la qual señalé [e romançé] y esto fize escribir e por ende fize aquí este mio signo (rúbrica) en testimonio de verdad.

Bno Xarafi. Escrivano público. 


\section{La traducción fehaciente en la Granada del siglo XVI}

\section{El concepto de traducción fehaciente}

Por traducción fehaciente entendemos, en sentido lato, la traducción e interpretación autorizadas cuya función es crear efectos jurídicos o institucionales, generalmente inmediatos. Se caracteriza, aunque no siempre en la misma medida, por ser remunerada, estar sujeta a régimen disciplinario y disfrutar su artífice de un nombramiento o contrato que lo habilite para ello o, cuando menos, haber éste cumplido los requisitos formales de los procedimientos instituidos a efectos de habilitación para una actuación concreta ${ }^{40}$. Son traductores e intérpretes con capacidad fehaciente en la España actual los traductores jurados, los traductores-intérpretes de la Administración de Justicia, los traductores-intérpretes de las Fuerzas de Seguridad del Estado, los miembros de la Oficina de Interpretación de Lenguas y los traductores adscritos a las embajadas y consulados de España. A ellos hay que añadir un nutrido grupo de trabajadores por cuenta propia, voluntarios o no tanto, que, con mayor o menor asiduidad, dan fe pública en nuestro país en materia de traducción e interpretación, así como, aunque sólo en teoría, los notarios y cónsules, por su capacidad fedataria universal. Como podremos comprobar en las páginas que siguen, los escribanos del siglo XVI, al menos en el Reino de Granada, ponían constantemente en práctica su capacidad fedataria universal también en el campo de la traducción y la interpretación.

\section{El concepto de traducción fehaciente y la literatura traductológica}

Hasta donde se nos alcanza, el concepto de «traducción fehaciente» no ha sido utilizado hasta el momento en los estudios de traducción ${ }^{41}$. Aunque no muy abundantes, sí existen trabajos dedicados a

${ }^{40}$ En la actualidad, por ejemplo, en el caso de una interpretación en un Juzgado, el haber jurado cumplir bien y fielmente el cometido para el que se le designa.

${ }_{41}$ Santoyo, J. C., Historia de la traducción. Quince apuntes, León, 1999, 9-33, por ejemplo, siguiendo parcialmente a Romano, D., "Hispanojudíos traductores del árabe", Boletín de la Real Academia de Buenas Letras de Barcelona, 43 (1992), 211-232, utiliza la denominación «traducciones cotidianas» o «de índole diaria». 
ámbitos parciales de la traducción o interpretación fehacientes, sobre todo a la traducción jurada y a la interpretación ante los tribunales. Pero, hasta ahora, no se había abordado la cuestión en los términos en que aquí los planteamos, ni tampoco se había utilizado el adjetivo «fehaciente» para definir este modo de traducción ${ }^{42}$.

La expresión «traducción fehaciente» procede de los estudios jurídicos, pero aun en estos ámbitos no es de uso universal. Es común en el discurso jurídico y administrativo en España hablar de traducción «oficial» (como en la Ley de Enjuiciamiento Criminal), traducción «auténtica» (como en los Convenios de cooperación judicial y de devolución de menores establecidos entre España y Marruecos), o traducción «autorizada», «certificada» o «certificada por persona autorizada» (como en el Convenio de Bruselas).

Naturalmente, el tema es del mayor interés para los estudios de historia de la traducción del árabe al español.

\section{La demanda de traducción fehaciente del árabe en la Granada del siglo XVI}

De manera sintética podemos afirmar que la implantación en el extinto reino nazarí, con una población mayoritariamente arabohablante, de una Administración en lengua castellana acarreó la lógica aparición de un notable mercado de traducción fehaciente tanto de textos escritos como de intervenciones orales. La necesidad de traductores e intérpretes en las distintas instancias del nuevo poder establecido fue un hecho manifiesto desde el momento mismo de la conquista. Así en el primer Concejo de la ciudad se nombra ya a un

\footnotetext{
42 Véase al respecto, Feria, M. C., La traducción fehaciente del árabe. Aunque dan mucho más de sí, a este tipo de cuestiones le ha dedicado varios trabajos Peñarroya, J., "Intérpretes jurados. Documentos para su historia", Boletín Informativo de APETI, 6 (1989), 31-32; "Intérpretes jurados. Documentos para su prehistoria", Boletín Informativo de APETI, 7 (1989), 27-28; "Intérpretes jurados en España. Número y distribución por comunidades autónomas en 1991", Boletín Informativo de APETI, 13, II (1991), 8; "Historia de los intérpretes jurados", Bulletí de l'Associació de Traductors i Intèrprets Jurats de Catalunya, 2000, sin paginar; "Historia de los intérpretes jurados", Conferencias del curso académico 1999-2000. Volumen conmemorativo del vigésimo aniversario de los estudios de traducción e interpretación de la Universidad de Granada, Sabio, J. A., Ruiz, J. y J. De Manuel (eds.), 161-78. Granada, 2000; "Historia de los intérpretes jurados". Traducción \& Comunicación, Vigo, 2000, 69-88.
} 
intérprete y trujamán ${ }^{43} \mathrm{y}$, en el año 1500 el mismo Concejo nombra a cuatro trujamanes oficiales que hubieron de pasar un examen previo y a los que se asignó un sueldo aproximado de unos dos mil maravedíes anuales; trujamanes de entre los que conocemos con seguridad a tres: Alonso Hernández de Mora, Ambrosio Xarafí y Antonio el Guahorani ${ }^{44}$. Sus labores - creemos- abarcarían tanto la traducción de documentos como la interpretación oral, aunque no de todos conocemos textos traducidos. Junto a estos trujamanes reconocidos, desde finales del XV y a lo largo de todo el siglo XVI, actuaron una verdadera legión de intérpretes ante todas las instancias oficiales: la propia corona, la justicia secular, el Santo Oficio, los escribanos públicos, los cabildos municipales, etc. A modo de ilustración, en la comarca de Motril, en un corto período de tiempo, actuaron al menos siete intérpretes distintos ${ }^{45}$. Y sólo en las escribanías de la capital granadina y entre los años 1510 y 1571 actuaron no menos de cuarenta y siete intérpretes ${ }^{46}$, muchos - como ocurre aún hoy-intérpretes o «lenguas», ocasionales aunque podemos encontrar entre ellos algunos tan profesionalizados como Alonso de Carvajal (con actuaciones documentadas entre 1546 y 1565) o Alonso de Herrera el Hadiz (con actuaciones documentadas entre 1542 y 1570$)^{47}$.

Pero, por razones obvias, es el mercado de la traducción fehaciente de textos - la traducción jurada si se nos permite el anacronismo- el que aquí nos interesa. El contenido de los romanceamientos que han sido editados hasta la fecha nos da una idea aproximada de cuáles eran las demandas en la Granada del momento. La mayoría de las actas notariales árabes traducidas $\longrightarrow$ al menos las conservadas - en el Reino de Granada son escrituras de propiedad de particulares (como las edita-

\footnotetext{
${ }^{43}$ Chalmeta Gendrón, P., El señor del zoco en España, Madrid, 1973, 458.

${ }_{44}$ Véase al respecto López Nevot, J. A., La organización institucional del municipio de Granada durante el siglo XVI, Granada, Universidad, 1994, 310; López de Coca Castañer, J. E., "El trabajo de mudéjares y moriscos en el Reino de Granada", VI Simposio Internacional de Mudejarismo, 97-136, Teruel, 1995, 134 y García Pedraza, Actitudes ante la muerte, t. 1, 471.

${ }^{45}$ Porras Arboledas, P. A., "Documentos sobre musulmanes y judíos en archivos señoriales y de protocolos”, Cuadernos de Estudios Medievales, 16 (1991), 127-157.

${ }^{46}$ García Pedraza, Actitudes ante la muerte, t. 1, 475-477.

${ }^{47}$ No obstante, un intérprete con este mismo nombre actúa también en los años 1508 (Espinar Moreno, "Escrituras inéditas") y 1528 (Espinar Moreno, "Escrituras árabes romanceadas"), lo que hace plausible que nos encontremos ante dos personas diferentes.
} 
das en este trabajo), escrituras de delimitación de lindes entre concejos municipales, de cesión de privilegios por parte de los reyes moros a ciertos municipios, $o$, finalmente, testamentos en los que se hace mención de propiedades inmuebles. Estos romanceamientos, por otra parte, se insertan en pleitos entre particulares por la propiedad de bienes inmuebles, en pleitos relativos al reparto de las aguas, por lo que debían hacer prueba ante el Tribunal granadino de Aguas, o en pleitos jurisdiccionales entre los nuevos concejos municipales cristianos.

Todo ello se explica a la luz del enorme impacto de la conquista en punto a despoblamientos, repartimientos y fricciones entre nuevos propietarios cristianos y sus convecinos moros o cristianos nuevos. Así pues, frente a otros muchos detalles que nos muestran lo cerca que estaba el modo de trabajar de aquellos romanceadores del de los traductores jurados actuales, las circunstancias sociales e históricas marcan una diferencia abismal con el tipo de textos hoy traducidos: el mercado de la traducción fehaciente del árabe demanda hoy casi exclusivamente documentación personal, y nunca documentos de propiedad, con alguna excepción (generalmente vehículos a motor, por su carácter mueble). Sin embargo, el contenido de los textos traducidos en el siglo XVI se halla bastante más cerca del contenido de los textos traducidos fehacientemente durante el Protectorado español en Marruecos en la primera mitad del siglo XX, como demuestra la insistencia de la literatura colonial de la época en el derecho inmobiliario y en la documentación relativa a bienes raíces. Naturalmente, todo ello es concordante con las diferentes coyunturas históricas que enmarcan los traslados, circunstancias a las que la traducción fehaciente está siempre sometida ${ }^{48}$.

En contraste con la pléyade de intérpretes a la que antes hacíamos alusión, la traducción de textos escritos fue labor de un número de traductores curiosamente limitado. De hecho, a lo largo de todo el siglo XVI apenas cuatro romanceadores (Ambrosio y Bernardino Xarafí, Juan Rodríguez y Alonso del Castillo) muestran una actividad continua y notable en esta dirección. Ello explica la observación de Francisco Núñez Muley en su famoso Memorial respecto a la existencia de un único traductor de escrituras arábigas en todo el Reino:

${ }^{48}$ Para más detalles, véase Feria, La traducción fehaciente y Arias Torres, J. P. y Feria García, M. C., "La traducción en el Protectorado español. Entrevista con Rafael Olmo Villafranca", Trans, 7 (2003), 107-119. 
Pues en decir la dicha prematica que las escrituras y titulos e libros e qualquier cosa escrita en aravigo que se an de exibir e presentar dentro en treynta dias en esta çibdad ante vuestra señoria y ante quien para ello sea nombrado, so las penas contenidas en este artículo [...] que posibilidad avra para juntarse tanto numero de escrituras para presentarse dentro del dicho termino e si posible fuesen que se juntasen que persona o personas bastarian para ante quien se presentase. Pues entremos al perjuyzio notorio que ay en que no uviese escrituras ni titulos ni libros ni cosa escrita en aravigo: pues que las escrituras e titulo ay estrema nesçeçidad de ellas [...] pues digamos questos se pudiesen romançar, en que termino se bastarian a rromançar o que rromançeadores bastarian para rromançear todo el rreyno, pues no ay mas que uno, de manera que exhibidos en arabigo se perderian, y acabados tres años no valdran nada como la prematica lo manda ${ }^{49}$.

Así pues, pasamos a ocuparnos de este reducido grupo.

\section{Los romanceadores granadinos del primer tercio del siglo XVI}

A partir de las leyendas que acompañan sus romanceamientos, podemos dividir a estos traductores inicialmente en tres grupos:

a) En primer lugar, los alfaquíes, como el citado alfaquí anónimo de Málaga, Mahoma Broçon (quien romancea seis escrituras en Granada, sin que conste la fecha exacta del traslado), o Yuça el Mudéjar, autor del romanceamiento editado más antiguo, el cual data del año de $1494{ }^{50}$. Como es lógico, estos alfaquíes firmaron como tales hasta su conversión. Tras abrazar la fe de Cisneros, si continuaron con su actividad traductora, como veremos en el caso del alfaquí Xarafí, ocuparon nuevos cargos en la administración granadina.

b) En segundo lugar, quienes se declaran romanceadores o intérpretes, como Alonso del Castillo o Fernando de Sosa.

49 Reproducción de la edición de Foulché-Delbosc, 1899, por Bernard Vincent en la introducción a Gallego Burín, A. y Gámir Sandoval, A., Los moriscos del Reino de Granada según el Sínodo de Guadix de 1554, ed. fac. 1996, LI.

50 Sabemos que este alfaquí fue nombrado regidor de Granada por los Reyes Católicos en mayo de 1492 y que colaboró en la administración del regadío granadino (López de Coca Castañer, J. E., "La emigración mudéjar al Reino de Granada en tiempo de los Reyes Católicos", En la España Medieval, 26 (2003), 203-226, 208). Respecto a Mahoma Broçon, véase Espinar Moreno, M., "De la mezquita de Maharoch". Respecto al alfaquí anónimo malagueño, Bejarano, F., Documentos del reinado de los Reyes $\mathrm{Ca}$ tólicos. 
c) Y por último, aquellos romanceadores que ejercieron al tiempo como escribanos públicos, ya fuere del rey o del Concejo granadino, como es el caso de Ambrosio, Bernardino e Íñigo Xarafí o de Juan Rodríguez.

Concretando un poco más, en la Granada de finales del XV y primera mitad del XVI, época en la que se trasladan los documentos que aquí editamos, destacan los siguientes romanceadores ${ }^{51}$ :

\section{Juan Rodríguez}

Es el traductor fehaciente más importante de los años en los que ejerció como tal $\mathrm{y}$, por tanto, un mediador fundamental entre las dos comunidades. En la leyenda de traductor se declara: «Escribano de su Majestad, romanceador de las escrituras arábigas, escribano público de los del número y romanceador de Granada y su tierra». Por consiguiente, concurren en su persona la calidad de fedatario universal, en cuanto que escribano público y escribano de su Majestad, y la de fedatario en traducción, en cuanto que romanceador de Granada y su tierra.

Destaca tanto por el número de romanceamientos y escrituras árabes suyas que conocemos - más de un centenar entre los editados y los sólo referenciados ${ }^{52}$-, como por el calibre de los asuntos en ellos

51 No incluimos a los intérpretes.

52 Cfr. González Palencia, "Documentos árabes del Cenete" y "Adiciones a los documentos árabes del Cenete", Al-Andalus, 6 (1941), 477-480; Seco de Lucena, L., "Documentos árabes granadinos"; Osorio, "Regesta de documentos granadinos"; Osorio y Santiago, Documentos arábigo-granadinos; Albarracín Navarro, J., Espinar Moreno, M. y Martínez Ruiz, J., El Marquesado del Cenete: Historia, Toponimia y Onomástica, según documentos árabes inéditos, Granada, 1986; Espinar Moreno, M., "Reparto de las aguas del río Abrucena", Crónica Nova, 15 (1986-1987), 127-147, y Espinar, "El reparto de las aguas del río Alhama"; Grima Cervantes y Espinar Moreno, "Estudio de algunas cartas"; Espinar Moreno, M. y Fernández Ortega, A., "Bab al-Hadid o Puerta del Hierro, según un documento árabe de 1495. Noticias para su ubicación", Revista del Centro de Estudios Históricos de Granada y su Reino, 3 (1989), 183-198; Martínez Ruiz, J., "Compra de bienes mudéjares granadinos", Actas del IV Simposio Internacional sobre Mudejarismo: Economía (17-19 sept. 1987), 443-452, Teruel, 1992; Albarracín Navarro, J., "La seda, moneda de intercambio en la Granada mudéjar", Actas del IV Simposio Internacional sobre Mudejarismo: Economia (17-19 septiembre 1987), 453-462, Teruel, 1992; Tri1lo, "Dos cartas árabes romanceadas"; Espinar Moreno, M., "Escrituras árabes romanceadas sobre la acequia de Ainadamar (siglo XIV-XVI)", Sharq al-Andalus. Homenaje a M. ${ }^{a}$ 
ventilados: empadronamientos arábigos del Marquesado del Cenete, reparto de aguas de diversas localidades del Reino de Granada y del Albaicín, cartas de privilegios de los habitantes de Huércal, además de numerosas transacciones cotidianas de propiedades. De los traslados editados se colige que estuvo en ejercicio durante unos cincuenta años, entre 1507 y 1552, lo que supondría que comenzó a ejercer muy joven y murió de avanzada edad ${ }^{53}$, aunque, como veremos ilustrado en el ejemplo de los Xarafí, no cabe en absoluto descartar que nos encontremos en realidad ante dos escribanos romanceadores homónimos, probablemente padre e hijo.

Martínez Ruiz ${ }^{54}$ nos lo retrata como traductor «bien conocido y de gran competencia» y destaca en su trabajo sobre el Marquesado del Cenete su habilidad para interpretar y dar valor exacto a las cifras rumíes relativas a las dimensiones de las fincas y su valor en pesantes y dineros.

Por desgracia, prácticamente no sabemos nada sobre su historia personal. Sólo podemos aventurarnos a decir que en varios de sus traslados aparecen como testigos Lope Rodríguez y Diego Rodríguez, muy probablemente familiares y herederos naturales de su oficio. De lo que no cabe duda es de que se trata de una figura de primer orden en la historia de la traducción del árabe al español, merecedora, por tanto, de estudios más profundos.

\section{Fernando o Hernando de Sosa}

Este romanceador vertió al castellano el 30 abril de 1506 veintiún documentos, agrupados en 16 escrituras, cuyos originales árabes data-

Jesús Rubiera Mata, 10-11 (1993-1994), 347-351; Álvarez de Morales, C. y Jiménez de Alarcón, M., "Pleitos de agua en Granada en tiempos de Carlos V. Colección de escrituras romanceadas", M. ${ }^{\text {a }}$ J. Rubiera (coord.), Carlos $V$, los moriscos y el islam, Universidad de Alicante, 2001, 59-90.

${ }_{53}$ En el supuesto plausible de que fuera morisco, debemos tener en cuenta la edad avanzada que muchos de ellos alcanzaron. A modo de ejemplo, la edad media de los testigos en el pleito entre Vera y Lorca en 1512 fue «de sesenta a setenta años, no siendo la extraña la presencia de individuos con ochenta, noventa e incluso con cien años» (Abad Merino, M. y Jiménez Alcázar, J. F., "Ítem si sabe...: el testigo morisco en los pleitos civiles castellanos", M. ' J. Rubiera (coord.), Carlos V, los moriscos y el islam, Universidad de Alicante, 2001, 27-38, 36).

${ }^{54}$ Martínez Ruiz, "Compra de bienes”, 442. 
ban de entre los años 1430 y $1496{ }^{55}$. Firma dichos traslados en calidad de «Yntérprete de sus Altezas», lo que suponía que su capacidad para dar fe pública en materia de traducción se extendía a todo lo largo y ancho de las tierras bajo soberanía de los Reyes Católicos, y no exclusivamente al Reino de Granada. En septiembre de ese mismo año romancea junto a Alonso Hernández de Mora varios documentos relativos a las propiedades de los infantes don Fernando y don Juan que fueron utilizados en sus probanzas y donde se afirma «que es persona vien esperta en la dicha lengoa arábiga e en nuestra lengoa castellana y son personas que saben la xara çuna de los moros, e que sabran vien declarar e interpretar las dichas cartas de arábigo en nuestra lengoa e letra castellana» ${ }^{56}$.

Es muy digno de notar que en sus romanceamientos encontramos soluciones que difieren en buena medida de la forma de proceder de otros destacados romanceadores contemporáneos o de años inmediatamente posteriores, incluyendo a los Xarafi, Juan Rodríguez o Alonso del Castillo, todos ellos en principio mudéjares o moriscos de origen. Ello nos hizo sospechar desde un principio que no fuera cristiano nuevo de moros, antes bien de judíos o, incluso, cristiano viejo. De hecho, Fernando de Sosa ha resultado no ser otro que el judío Gabriel Israel, recaudador de impuestos de Llerena, su ciudad natal, más tarde Trujamán Mayor del Reino de Murcia desde el año de 1476, lo que explica que firme sus traducciones como «Yntérprete de sus Altezas», diligente mediador en las negociaciones que condujeron a las capitulaciones de Ronda, recaudador mayor de Málaga y su partido entre 1494-96 y uno de los últimos judíos - si no el último- que disfrutó de nombramiento regio en la Península ${ }^{57}$.

${ }^{55}$ Dichos traslados fueron incluidos como prueba en el pleito que el convento de Santa Cruz la Real entabló con García de Vargas por la propiedad de un corral medianero en la plaza de Bibatuabín (Osorio Pérez, M. ${ }^{a}$ J. y Peinado, R. G., "Escrituras romanceadas del Convento de Santa Cruz la Real (1430-96): pinceladas documentales para una imagen de la Granada nazari', Miscelánea de Estudios Arabes y Hebraicos, 51 (2002), 191-217.

56 Malpica Cuello, A. y Trillo Sanjosé, C., "Los infantes de Granada. Documentos árabes romanceados", Revista del Centro de Estudios Históricos de Granada y su Reino, 6 (1992), 361-421.

57 López de Coca Castañer, J. E., "La fiscalidad mudéjar en el reino de Granada", Actas del V Simposio Internacional de Mudejarismo, Teruel, 1991, 203, basándose en los trabajos de Morales García-Goyena, identificaba a Fernando de Sosa con el judío Yscará, antiguo colaborador de Gabriel Israel. Sin embargo, el mismo profesor López de Coca ha tenido la gentileza de informarnos en comunicación personal de que muy posiblemente 


\section{Otros traductores}

Acabamos de hacer mención a Alonso Hernández (o Fernández) de Mora, intérprete, «el qual sabe leer y escreuir de arábigo», quien, además de intervenir en los recién citados traslados sobre las propiedades de los Infantes de Granada, romancea dos cartas de venta ${ }^{58}$. Es de destacar que este personaje pertenece a una familia de origen mudéjar ligada al mundo de la trujimanería a cuya cabeza estaba su padre, Rodrigo de Mora (antes Yuçaf de Mora), quien muy posiblemente sea el antes aludido Yuça el Mudéjar, y a la que puede que también pertenezca el Lorenzo de Mora que actúa como testigo en las actas que aquí editamos.

Por otra parte, en las probanzas de los Infantes intervinieron varios traductores más: Alonso Venegas, regidor y alguacil mayor de Granada, hijo que fue del infante de Almería Yahya al-Nayar, después Pedro de Granada ${ }^{59}$, a quien «sus Altezas tienen nombrado por truxaman mayor para que declare de lengoa arábiga en castellano las cosas que en esta çibdad sucedieren» ${ }^{60}$; y Miguel de León, «regidores desta dicha çibdad, que antes se llamava alfaquí cadí Maomad Zaharori». Y por último, el ya conocido Ambrosio Xarafí.

De este último romanceador y de Bernardino Xarafí, autor de los romanceamientos aquí editados, pasamos a ocuparnos a continuación con mayor detenimiento.

\footnotetext{
Goyena había incurrido en un error de lectura. Por otra parte, el relato completo de las actuaciones que se siguieron por los abusos y fraudes cometidos por Fernando de Sosa aprovechando su conocimiento del antiguo fisco granadino, pueden también leerse en el citado trabajo de López de Coca, "La fiscalidad mudéjar". En general, respecto a Ysrael véase Feria, La traducción fehaciente, 196-199.

58 Santiago, "Algunos documentos arábigo-granadinos".

${ }^{59}$ López de Coca Castañer J. E., "Granada en el siglo XV: las postrimerías nazaríes a la luz de la probanza de los infantes don Fernando y don Juan", Andalucia entre Oriente y Occidente (1236-1492): Actas del V Coloquio Internacional de Historia Medieval de Andalucía, 599-641, Córdoba, 1988, 610.

${ }^{60}$ Malpica Cuello, A. y C. Trillo Sanjosé, “Los infantes de Granada”, 387.
} 


\section{Los Xarafí, una familia de trujamanes fedatarios públicos}

\section{Mahomad, Hamete, Abraham y Ali Xarafi}

Según Molénat ${ }^{61}$ el apellido Xarafí es sin duda la versión castellana de la nisba geográfica referida al Aljarafe sevillano. Son numerosos los andalusíes de todas las épocas conocidos por al-Šarafĩ o Ibn al-Šarafî, muchos de ellos vinculados a las ciudades de Sevilla y Córdoba y a cargos de importancia en sus respectivas comunidades. Esta posición notable se mantuvo en época mudéjar en diferentes zonas de la Península, en las que distintos miembros de esta familia ejercieron como alcaldes mayores de las aljamas, cargo que, heredero del de cadí, incluía entre sus funciones la capacidad de actuar como notario. Siguiendo al investigador citado, los primeros datos de la familia destacables para nuestros fines se remontan al año de 1347. En esa fecha y en la ciudad de Toledo, Mahomad Xarafí y su hijo Hamete, en calidad de alcadíes y traductores, firman en árabe y castellano la traducción oficial «en ladino» de dos escrituras de compraventa por las que el Arzobispo de Toledo, D. Ruy Ximénez, adquiere «el castiello nombrado Cihuruela» ${ }^{62}$. Años más tarde, concretamente en 1369 , otro hijo de aquél, de nombre Abraham, ejerce como «alfaquí del aljama de los moros de Toledo». Y para finales de ese siglo lo sustituye su hijo, de nombre Hamete. En esta misma época, miembros de la familia, o al menos de igual apellido, están bien asentados en Alcalá de Henares, donde también ocupan puestos de responsabilidad. Es el caso de Alí Xarafi, alcalde de moros de esta ciudad hacia 1351.

Ya en la segunda mitad del siglo XV encontramos a otro alfaquí Alí Xarafí encargado de la recaudación de impuestos en las aljamas del Reino de Toledo. Pero será un nuevo Abraham Xarafí, alfaquí y médico al servicio del arzobispo de Toledo, Alonso Carrillo, el miem-

${ }^{61}$ Molénat, J-P., "Une famille de l'elite mudejare de la Couronne de Castille: les Xarafi de Tolede et d'Alcalá de Henares", A. Temimi (ed.), Mélanges Louis Cardaillac, Túnez, 765-772. Este investigador ha dedicado otros estudios a esta familia, cuya lista puede verse en Echevarría Arsuaga, A., "De cadí a alcalde mayor. La élite judicial mudéjar en el siglo XV (I)", Al-Qantara, XXIV (2003), 1, 139. Además de en el último artículo citado, Echevarría se ha ocupado de la familia Xarafi en "De cadí a alcalde mayor. La élite judicial mudéjar en el siglo XV (II)", Al-Qanțara, XXIV (2003), 2, 273-290.

${ }^{62}$ Este documento, utilizado por Molénat en su estudio, fue editado por Fita, F., "Marjadraque según el fuero de Toledo", Boletín de la Real Academia de la Historia, 7 (1885), doc. 5, 371-376. 
bro de esta familia que mayor renombre alcance en este período. Nombrado inicialmente en 1473 alcalde de las aljamas de Ávila y Aranda por la entonces princesa Isabel bajo la promesa de hacer extensible su cargo a todas las aljamas del reino, y confirmado en el cargo en 1488 tras una reñida y larga disputa con Farax de Belvís, miembro de otra de las familias mudéjares castellanas de mayor influencia, recibirá finalmente de los Reyes Católicos en 1492 el nombramiento de alcalde mayor de la aljamas de los Reinos de Castilla ${ }^{63}$, cargo que aún ejercía el 30 de marzo de 1496, cuando, a través del alfaquí de la aljama de moros de Palencia, Alí Alvar Ruiz, y habida cuenta de la protesta de la morería de Ávila, solicita en Valladolid al corregidor de esta última localidad averigüe cómo se ejercía la justicia civil y criminal en la aljama ${ }^{64}$. La última referencia que hemos encontrado de este personaje es la descripción hecha por Wagner ${ }^{65}$ de un acta notarial levantada en Sevilla el 8 de octubre de 1499, y en la que leemos lo siguiente:

Alfonso Fernández, criado de Juan de Sandoval, vecino de Sevilla, en la colaçión de San Román, otorga que ha recibido de maeste Çayde, alcalde de la aljama de los moros, tres reales por llevar y entregar al alfaquí Xarafí un pleito que ante él pende entre la una parte de maeste Hamete Carmoní y de la otra doña Merien e doña Fotox. Otorga que recibió real y medio; el resto se le pagará cuando traiga la fe del alfaquí.

Empero, es en fecha un poco anterior y en el Reino de Murcia donde volvemos a hallar testimonio de la labor de esta familia de alfaquíes en el mundo de la traducción. Concretamente, en el nombramiento del mencionado Gabriel Israel como «yntrépetre e truxamán mayor de la letra e lengua aráuiga e morisca» del Reino de Murcia, fechado el 29 de junio de 1476, leemos lo siguiente:

as cosas e fechos e contratamientos que nasçieren e ouieren de faser e contratar entre el nuestro reyno de Murçia y Arabaca e la vaylía e helén con el rey e reyno e moros de Granada, en lugar del alfaquí Alí Xarafí, intérprete e troxamán que

${ }^{63}$ Una completa exposición sobre las disputas por el cargo de alcalde mayor de los Reinos de Castilla entre las familias Xarafí y Belvís puede verse en Echevarría Arsuaga, "De cadi a alcalde mayor".

64 Archivo General de Simancas, Registro General del Sello, Volumen XIII (enero-diciembre de 1496), C. Álvarez Terán, Madrid, 1987, 85, doc. 523.

${ }_{65}$ Wagner, K. (1978), Regesto de documentos del archivo de protocolos de Sevilla referentes a judios y moros, Sevilla, 1978, 79-80. 
fue de la lengua arábiga [...]. E es nuestra merçed e voluntad que todas las letras escripturas, e otras quealesquier cosas de la dicha lengua aráuiga que se ouieren de enbiar o traher del dicho rey o reyno de Granada, sean interpretadas e declaradas por vos el dicho Gabriel Ysrael ${ }^{66}$.

Por tanto, hasta el año 1476, o en todo caso hasta fechas poco anteriores, el alfaquí Alí Xarafi - puede que el mismo que en 1451 se encargaba de la recaudación de los impuestos de los mudéjares al servicio de Juan II- era «yntrépetre e truxamán mayor de la letra e lengua aráuiga e morisca» de la bailía y del Reino de Murcia. Sus predecesores en el cargo hasta principios del siglo XIV son medianamente conocidos ${ }^{67}$ : en el año 1308 el judío Isaach Vital fue sustituido en el cargo por Alfonso Guillem; y en el año 1360 fue ocupado por el judío Iuçeff Abencavarell, hasta 1367, en que lo sustituye Abrahim Abenhave ${ }^{68}$. Por otra parte ${ }^{69}$, hasta el año 1424 , el puesto había sido desempeñado por personalidades muy destacadas de las aljamas de moros, tales como Alí Xupió o el alcadí Alí de Bellvís ${ }^{70}$. Cabe suponer, por consiguiente, que Alí Xarafí ocupó el cargo en los años comprendidos entre 1424 y 1476 , demasiados para que lo disfrutase en exclusividad.

\section{El alfaqui Xarafi y Hamete Xarafi}

Entre el año 1476 y el final de la Guerra de Granada no nos consta noticia alguna referente a Alí Xarafí. Sin embargo, Al-Xarafí, a secas, aparece citado con el cargo de intérprete en el Concejo que se nombra inmediatamente después de la conquista de la ciudad de Granada ${ }^{71}$.

El siguiente dato documental es que el 15 de abril de 1496 un «alfaquí Xarafi» actúa como romanceador en el Reino de Granada ${ }^{72}$. En principio podríamos pensar que se trata de Abraham Xarafí o quizás,

${ }^{66}$ García Casar, M. F., "Trujimanes judíos al servicio de los Reyes Católicos", Helmántica, 103-105 (1983), 191-196, 193 y n. 11.

${ }^{67}$ Barceló, C., Minorías islámicas en el País Valenciano. Historia y dialecto, Valencia, 1984, 138 y ss.

${ }^{68}$ Citado también por Romano, "Hispanojudíos traductores del árabe".

${ }^{69}$ Hinojosa Montalvo, J., "El trabajo mudéjar en la Valencia medieval", VI Simposio Internacional sobre Mudejarismo, Teruel, 1995, 82 y n. 81.

${ }^{70}$ Sobre esta notable familia de alcadíes puede verse Molénat, "Une famille de l'elite", 765, n. 1 y 2, y, sobre todo, Echevarría, "De cadí a alcalde mayor".

71 Chalmeta, El señor del zoco, 458.

${ }^{72}$ López de Coca Castañer, J. E., La tierra de Málaga, doc. n. ${ }^{\circ}$ 95, 596-597. 
incluso, de Alí Xarafí, veinte años después de cesar como romanceador en Murcia, en especial si tenemos en cuenta que la Guerra de Granada atrajo a no pocos mudéjares castellanos y murcianos prestos a colaborar y, de paso, medrar. No obstante, un año después, concretamente el 5 de agosto de 1497, un acta de testimonio sobre la guía y venta de la sal de las salinas de Motril levantada el 10 de junio de 1493 en esa localidad es romanceada en Granada por quien firma como el "alfaquí Hamete Xarafi»»" ${ }^{73}$, "vezino desta dicha çibdad ques onbre que sabe las dichas lenguas [arábiga y castellana]» ${ }^{74}$. Y el 26 de septiembre de 1499 el alfaquí Hamet (sic) Xarafí, «escribano de la Xarra de Granada, fiel de sus altezas en la declaración de las escripturas moriscas de las ventas e compras... que se fasen entre cristianos e moros en la dicha ciudad de Granada é su Reino», traslada tres escrituras relacionadas con la venta de propiedades de la familia real nazarí en Huétor Santillán ${ }^{75}$. Por la cercanía de fechas parece muy probable que se tratase de la misma persona que romanceó el 15 de abril de 1496, y el mismo que, como señalábamos antes, fue nombrado intérprete del Concejo.

\section{Ambrosio Xarafi}

A partir de este momento, los Xarafí dejan de ser alfaquíes y, tras su conversión a la fe de Cisneros, pasan a convertirse en escribanos públicos, cargo que, al fin, y haciendo honor a la tradición familiar,

73 Porras Arboledas, "Documentos sobre musulmanes y judíos", 135.

74 A.H.N., Nobleza, Osuna, legajo 1354, n. 12, f. ${ }^{\circ} 73$ r.

75 A.G.S., Diversos de Castilla. Leg. 40, f. 30 . Debemos una vez más el dato y la descripción a la generosidad de López de Coca, quien hizo referencia a su vez al trabajo de Osorio Pérez, M. J., "Notas y documentos sobre un caballero granadino: Gómez de Santillán”, Actas del VI Coloquio Internacional de Historia Medieval de Andalucia: Las ciudades andaluzas (siglos XIII-XVI), Málaga, 1991, 486, n. 25. En él Osorio afirma que «en 1492 la poseía [la villa de Huete] Um al-Fath, hija de Boabdil, y que, al igual que otras posesiones personales de la casa real, pasó a manos de la corona castellana a través de un contrato otorgado ante el alfaquí Hamet Xarafi el 26 de la luna de Adulcayda del año 897 (16 de septbre de 1492) por el que la princesa vende al alcaide Juan de Haro la citada alquería por 1000 doblas de oro (400.000 maravedíes), pago que efectuó en paños, rasos, sedas, especias y una cadena de oro». Aunque la expresión «otorgado ante el alfaquí Hamet Xarafi» da a entender que éste actuó como escribano, lo cierto es que Xarafi no obtuvo tal nombramiento hasta ocho años después. 
podían sin quebranto considerar un traslado a aljamía del de alfaquí o «escribano público de moros».

El primero en aceptar el bautismo, y del que podemos ofrecer más detalles biográficos, fue miçer ${ }^{76}$ Ambrosio Xarafí ${ }^{77}$, nacido aproximadamente en el año de $1450{ }^{78}$, esposo de doña Mayor de Mendoza Xarafía ${ }^{79}$. Ya se hallaba en Granada en los años anteriores a su conquista, ciudad en la que ocupaba una posición importante, pues residía nada menos que en casa del alcaide mayor Yusuf Abencomixa ${ }^{80}$.

Ambrosio Xarafí fue nombrado escribano de los del número de la ciudad de Granada el día 23 de septiembre del año de 1500, tres días después de que se instituyera el Ayuntamiento de la capital ${ }^{81}$. Contaba a la sazón cincuenta años de edad. Posteriormente le sucedieron en

${ }^{76}$ El tratamiento «miçer» que adoptó y el propio nombre de Ambrosio hacen pensar a López de Coca (comunicación personal) que su padrino de bautismo fuera de origen italiano, extremo en nada extraño, ya que, según Ladero Quesada, M. A., "Nóminas de conversos granadinos", J. E. López de Coca (ed.), Estudios sobre Málaga y el Reino de Granada en el V centenario de la conquista, Málaga, 291-311, 297, se encuentran mercaderes genoveses ejerciendo de padrinos en la zona y por los mismos años. Casualmente hemos encontrado entre la nómina de italianos mercaderes estudiados por Obra Sierra, J. M., Mercaderes italianos en Granada (1508-1512), Granada, 1994, a un miçer Ambrosio de Spíndola (doc. 1) y a un Ambrosio de Cavali (doc. 56) que bien pudieran haber aceptado el apadrinamiento. Esta identificación quizá podrá comprobarse cuando Ladero Quesada edite las nóminas bautismales de la época, proyecto en el que trabaja desde hace tiempo.

77 En sus distintas variantes de escritura latina: Anbrosyo o Anvrosyo, Xarafi, Xarafin, Xarafil, Jarafi, Gerafi y Yarafi.

78 En el año de 1506, Ambrosio Xarafí manifiesta que contaba a la sazón 56 años de edad en el famoso pleito sostenido por los infantes don Fernando y don Juan de Granada (López de Coca, "Granada en el siglo XV", 612, 640 y López de Coca, "El trabajo de mudéjares y moriscos", 134).

79 Obra Sierra, J. M., “Aproximación al estudio de los escribanos públicos del número en Granada (1427-1520)", Ostos Salcedo P. y Pardo Rodríguez, M. L. (eds.), El notariado andaluz en el tránsito de la Edad Media a la Edad Moderna, Sevilla, 1995, 136. déjar".

${ }^{80}$ López de Coca, "Granada en el siglo XV" y López de Coca, "La emigración mu-

81 A.G.S., R.G.S. (Galán Sánchez, A., Los mudéjares del Reino de Granada, Granada, 1991, 394, n. 127, y Obra Sierra, “Aproximación”, 170, n. 244). Junto a él lo fueron también el citado Alonso Fernández de Mora, y Juan (o Fernando) de Morales, hijo de Yahya el Fistalí, con igual cargo, todos ellos personajes ligados también al mundo de la trujamanería. En ese momento ya existían once escribanías públicas en la ciudad, con lo que pasaron a ser catorce. También en el año 1500 se nombró escribano del número a Fernando del Castillo, sobrino de su homónimo, el alguacil morisco colaborador de Purchena, cuyos descendientes constituyen igualmente una saga de escribanos. En 1503, se añadiría a esta nómina Antón Andrés el Baztí, también morisco (Galán Sánchez, Los mudéjares, 395 y Obra Sierra, "Aproximación”, 135). Esto, sin contar con otros escribanos moriscos que ejercieron fuera de la capital. 
el cargo sus hijos Bernardino, escribano de los del número como él, a más de escribano de sus majestades y romanceador de los textos que dan pie a estas páginas, e Íñigo Xarafí, escribano del rey ${ }^{82}$. No encontramos, pues, ante un caso claramente precursor del de Gonzalo y Alonso Fernández Gabano - padre e hijo-, los Fustero o Juan Fernández Albotodo, todos escribanos públicos moriscos de la ciudad de Granada, aunque ya de mediados del siglo XVI, de algunos de los cuales tenemos noticia documentada de que también ejercieron en ocasiones como intérpretes ${ }^{83}$.

Así pues, todo parece indicar que miçer Ambrosio Xarafí no es otro que el «alfaquí Hamete Xarafi» ${ }^{84}$, de origen mudéjar castellano que podría remontarse hasta los Xarafí de Toledo, pariente - posiblemente hijo- de Alí Xarafí, el «yntrépetre e truxamán mayor de la letra e lengua aráuiga e morisca» del Reino de Murcia hasta el año 1476. Hamete, por tanto, debía de tener unos veintiséis años al momento de cesar Alí, con quien es de suponer que aprendió el oficio en el Reino de Murcia siguiendo la larga tradición de la trujamanería mudéjar. Instalado en Granada, y atraído por las posibilidades que ofrecía la nueva situación, habría colaborado con los conquistadores - como tantos otros - lo que le valió el cargo de intérprete del Concejo de Granada y, tras su conversión, que presumiblemente tuvo lugar en el año 1500, el de escribano público de los del número, es decir, los que probablemente eran los puestos de mayor grado a que podía aspirar en el Concejo, primero, y Ayuntamiento, después, de la capital granadina. Se trata, por tanto, del romanceador oficial de la época, del mismo modo que después lo fueron Juan Rodríguez y Alonso del Castillo. El dato de su origen mudéjar no granadino no debe ser inadvertido. No caben muchas dudas, pues, de que al insta-

82 También conocemos la existencia de su hija Guiomar Xarafia, a la cual desposó el 11 de diciembre de 1508 con Juan de Rojas, albañil, vecino de Granada, mediante una dote de 150.000 maravedíes (Osorio Pérez, M. J., "Aproximación al status socio-económico de la mujer morisca a través de los protocolos granadinos: fuentes para su estudio", Actas del IV Simposio Internacional sobre Mudejarismo: Economía (17-19 septiembre 1987), Teruel, 1992, 667-75, doc. 1).

${ }^{83}$ Véase al respecto García Pedraza, Actitudes ante la muerte, t. 1, 332 y ss.

${ }^{84}$ Esto mismo parece sugerir López de Coca, "El trabajo de mudéjares" y "La emigración mudéjar". Siendo así, no podemos estar de acuerdo con Galán Sánchez, Los mudéjares, 1991, 394-395, quien considera el nombramiento de Ambrosio Xarafi entre las medidas adoptadas por las autoridades granadinas para integrar a los mudéjares del Reino. 
larse en Granada en los últimos años de la década de los ochenta su intención no era la de servir a los nazaríes sino, más bien, la de iniciar unas labores de intermediación — si no de espionaje- que se sucederían en las personas de sus hijos a lo largo de la primera mitad del siglo XVI. Nos encontramos, en definitiva, con un representante destacado del grupo de «alfaquíes» que, junto a la nobleza nazarí y ciertos mercaderes adinerados, se integran sin ambages en la vida social y económica de la ciudad.

Los romanceamientos de 15 de abril de 1496 y 5 de agosto de 1497 no son las únicas pruebas documentales de la dedicación de Hamete-Ambrosio Xarafí a la traducción e interpretación desde mediados de los años noventa del siglo $\mathrm{XV}{ }^{85}$. Sabemos, por ejemplo, que en el mismo período colaboró con Juan de Porras, tesorero de Vizcaya, en las pesquisas realizadas con objeto de averiguar el paradero de bienes de la casa real granadina, tarea en la que romanceó diversas escrituras ${ }^{86}$. Debió de tratarse de una labor a él encomendada en calidad de trujamán del Concejo granadino, pero la importancia del encargo muestra una vez más la confianza en él depositada por parte de las autoridades castellanas.

También se han conservado y editado romanceamientos suyos fechados el 23 de noviembre de $1501^{87}$ y el 12 de febrero de $1502^{88}$. En este último documento, miçer Ambrosio se declara «escriuano del Rey y de la Reyna, nuestros Señores, y Escriuano público de los del Número de la dicha çibdad» (es decir, de Granada). Concurrían en él, por tanto, los cargos de escribano del rey y del número, como también ocurría en el caso de Juan Rodríguez, lo que le proporcionaba sin duda una capacidad de actuación muy amplia. A los seis romanceamientos citados debemos sumar otros seis editados en la segunda mitad de los años noventa y fechados entre julio de 1503 y octubre de 1506, correspondientes a originales de entre 1449 y 1477, además de

${ }^{85}$ Al parecer, los nuevos escribanos moriscos de Granada disfrutaron de la posibilidad de delegar la escribanía hasta que adquirieran suficientes conocimientos de la lengua castellana (Galán Sánchez, Los mudéjares, 394). No debió ser el caso de Ambrosio Xarafí.

${ }^{86}$ López de Coca, "Granada en el siglo XV", 612.

87 González Palencia, "Documentos árabes del Cenete", doc. 4, 363, transcribe el nombre del romanceador como "Ambrosio Parasy». Debe de tratarse de una lectura defectuosa.

${ }^{88}$ Garrido Atienza, Los alquézares de Santafé. 
cincuenta y siete escrituras de compraventa - muy escuetas- levantadas entre mayo y octubre de 1492 por las que Gómez de Santillán había adquirido tierras en Chauchina (Granada), romanceadas el 21 de agosto de 1503 por Ambrosio Xarafí y Alonso Venegas, «Trujamán mayor de sus Altezas» ${ }^{89}$. En total, por tanto, casi setenta romanceamientos editados.

$\mathrm{Su}$ actividad como notario fue también muy intensa, como en general la de todos los escribanos moriscos de la capital. Prueba de ello la tenemos en sus protocolos, heredados tras su renuncia por su hijo y, a la muerte de éste, depositados el 25 de noviembre de 1521 por la esposa del primero y madre del segundo, doña Mayor de Mendoza Xarafía, ante el escribano público del número Juan de la Rentería. En total, diecinueve registros de escrituras públicas ${ }^{90}$. Desgraciadamente no se han conservado, pues fueron pasto de las llamas que asolaron el Archivo de Protocolos de Granada en la navidad del año de 1879 9!, pero sí disponemos de numerosas referencias a escrituras otorgadas, tanto por Ambrosio como por Bernardino obrantes, sobre todo, en los registros de los escribanos de Granada Juan Rael, Juan de Alcocer y Gaspar de Arias ${ }^{92}$. A ello debemos sumar, en palabras de Obra Sierra, «sus intervenciones como trujamanes, en las cuales no se limitan a la mera traducción al castellano de documentos escritos en letra arábiga, sino que actúan dando fe, como escribanos públicos que son, de la fidelidad del traslado con el original».

Por último, es prueba de la importante posición que debió ocupar entre los escribanos de la ciudad, y de la confianza que en él se depositaba, una carta del licenciado Morillas, dirigida a su Alteza y fechada el 15 de julio de 1548, en la que aquél da noticia de las diligencias

89 Jiménez Alarcón M. y C. Álvarez de Morales, "La huerta del Rey Moro. Noticias de la Granada Nazarí a través de los documentos romanceados", Revista del Centro de Estudios Históricos de Granada y su Reino, 10 (1997), 115-131; Peinado Santaella, R., "Una aportación documental sobre el poblamiento, el paisaje agrario y la propiedad de la tierra de dos alquerías de la Vega de Granada: Chauchina y el Jau a finales del período nazarí", Revista del Centro de Estudios Históricos de Granada y su Reino, 10-11 (1996-1997), 19-92.

90 A.P.G., Prot. n. ${ }^{\circ}$ 14, fol. 801 r-v. (Obra Sierra, “Aproximación”, 136).

${ }_{91}$ García Pedraza, Actitudes ante la muerte, t. 1, 331.

92 A.P.G., Prot. n. ${ }^{\circ}$ 1, 2, 3, 4 (Obra Sierra, ibidem). A éstos cabe añadir al menos los dos publicados por Espinar Moreno, "Escrituras árabes romanceadas", docs. 5 y 6, que este investigador presenta en la introducción como traducciones pero que - a nuestro juicio- no son tales sino escrituras otorgadas ante Ambrosio Xarafi en su calidad de escribano público. 
practicadas a fin de hallar copia de las capitulaciones para la entrega de Granada, y en la que leemos lo siguiente:

Se an hecho las diligencias que conbenían para aver la capitulación original que hizieron los Reyes catholicos nuestros Señores con muley baudili el zagal, Rei que fue desta ciudad de granada al tiempo que este rreyno se conquistó, de que ninguna rrazón Sea hallado en los hijos y herederos de ambrosio Xarafi, Scriuano público que fue desta cibdad, ni en los officiales que rresidieron en su oficio, ni Scribanos que Subcedieron en Sus rregistros y Scripturas [...] y por dicho de un Scribano que fue su official paresce que antel ambrosio Xarafi se traxo un priuilegio original, abrá treynta años, que se le dió el Rey baudili de granada para que el Xarafi sacase un traslado Signado ${ }^{93}$.

\section{Bernardino Xarafi}

Que tres miembros de una misma familia - Ambrosio, Bernardino e Íñigo- fueran escribanos no es inusitado ${ }^{94}$. Son muchos los ejemplos que demuestran, en cualquier caso, que era éste un oficio al que se accedía fundamentalmente a través de la renuncia de un escribano anterior, no siendo raras las renuncias a favor de familiares. En el caso que nos ocupa, Ambrosio Xarafí renunció a favor de su hijo Bernardino en noviembre del año 1510, a lo que siguió el nombramiento de éste el catorce de diciembre del mismo año ${ }^{95}$, es decir, después de una dedicación profesional de diez años ${ }^{96}$.

93 Editada por Garrido Atienza, Las capitulaciones para la entrega de Granada, Granada, 1910 (edición facsímil, Granada, 1992), doc. LXXV

94 Otros ejemplos aparecen referenciados en Obra Sierra, “Aproximación”, 140-141, y en García Pedraza, Actitudes ante la muerte, t. 1, 325 y ss.

95 A.G.S., R.G.S. (Obra Sierra, “Aproximación”, 170, nn. 241 y 245).

${ }^{96} \mathrm{El}$ hecho de que Bernardino se hiciera cargo de la escribanía de su padre, incluidas las labores como romanceador, explica ciertos fenómenos que indujeron a investigadores anteriores a considerar que se trataba de una sola y la misma persona. En esta dirección parece pronunciarse, por ejemplo, Garrido Atienza, M., Los Alquezáres de Santafé, 13 y n. 1, quien atribuye a un error de copia la aparición del nombre de Bernardino Xarafi en la parte dispositiva de la sentencia fechada el 30 de julio de 1530 - nada menos que treinta años después - a la que daría lugar la traducción del año 1502 realizada por Ambrosio tal y como reza en la traducción original suscrita por éste así como en el cuerpo de la sentencia (nótese igualmente que la atribución de la traducción original de este documento a Bernardino Xarafi en lugar de Ambrosio Xarafi hecha por Espinar Moreno en el estudio preliminar a la edición facsímil de esta obra, pp. L y LV-LVI, es errónea). El parecer de Garrido Atienza tiene precedentes. «Bernardino o Ambrosio Xarafi» aparece citado, como si de una sola persona se tratase, como fuente de arabismos en el Glosario Etimológico de las palabras españolas de origen oriental de L. Eguilaz y Yangüas, Granada, 1886. Así ocurre, por 
Aunque el nombramiento de Bernardino está fechado en 1510 , como decíamos, su aprendizaje e inserción en el oficio es anterior, como también en el caso de su padre y, como veremos a continuación, en el de su hermano Íñigo. Así, consta que ya en los años 1506 y 1508 Bernardino Xarafí, al que se califica de «vezino desta dicha çibdad» (de Granada se entiende) actúa como testigo en sendas escrituras protocolizadas por Ambrosio ${ }^{97}$. Sus primeras actuaciones como romanceador fehaciente, por tanto, debieron seguirse del nombramiento como escribano del número de 1510 , puesto que no nos consta nombramiento anterior que le habilitara para ello (frente a lo que veíamos en el caso de su padre). En cualquier caso, las primeras pruebas documentales conservadas de su labor en este campo son posteriores al año 1510. Concretamente, cuatro traslados de fecha 16 de agosto de 1514 y dos de 26 de junio de $1515^{98}$ en los que se declara «Escrivano de la Reyna e del Rey, su fijo, nuestros Señores, e Escrivano publico de Número de la dicha çibdad de Granada». Como en el caso de Ambrosio y de Juan Rodríguez, también en él coinciden ambos nombramientos. Esta leyenda se repite en los documentos de 1517 que aquí editamos y aparece resumida en otro documento del mismo año como «Escribano público de esta ciudad» ${ }^{99}$.

Las últimas actuaciones como romanceador conocidas se remontan al 5 de mayo de 1518, cuando actúa como romanceador de varios documentos relativos al reparto de aguas del río de la Ragüa ${ }^{100}$, donde le asisten como testigos - entre otros - el citado Miguel de León, Francisco Jiménez y Juan de Velasco Albarracín, y al 31 de julio de 1521 , fecha en que traslada cinco romanceamientos de originales del siglo XIII ${ }^{101}$.

ejemplo, al consignar la voz «adul», que Corriente, F., Diccionario de arabismos y voces afines en iberorromance, Madrid, 1999, s.v., considera «un tecnicismo tardío, no anterior a las empresas norteafricanas», cuando en realidad ya se usaba en las traducciones fehacientes del siglo XVI, más concretamente en las de los Xarafi.

97 Espinar, "Escrituras árabes romanceadas", docs. 5 y 6.

98 Santiago, "Algunos documentos arábigo granadinos".

99 Álvarez y Jiménez, "Pleitos de agua en Granada".

100 Espinar Moreno, M. y M. D. Quesada Gómez, "El regadío en el distrito del Castillo de Sant Aflay. Repartimento del río de la Ragüa (1304-1524)", Estudios de Historia y Arqueología Medievales, 5-6 (1985-1986), 127-158.

101 Espinar Moreno, M. y Quesada Gómez, M. ${ }^{\text {a }}$ D., "Las aguas del río Nacimiento del siglo XI al XVI. Noticias sobre el regadío y la agricultura en los alfoces de Marchena y Alboloduy según documentos notariales árabes y castellanos (1226-1527)", Revista del Centro de Estudios Históricos de Granada y su Reino, 7 (1993), 85-128. 
Apuntábamos antes que los protocolos de Ambrosio y Bernardino fueron depositados el 25 de noviembre de 1521 por doña Mayor de Mendoza Xarafia ante el escribano público del número Juan de la Rentería. Podemos deducir, por tanto, que Bernardino falleció entre el 31 de julio de 1521, fecha del último romanceamiento conocido, y el 25 de noviembre del mismo año.

\section{Ínigo Xarafi}

Para terminar con esta saga de traductores, los romanceamientos de Bernardino editados incluyen desde el año $1514{ }^{102}$, inclusive los dos que aquí editamos, referencia a otro miembro de la familia, Íñigo Xarafí, hermano de Bernardino, el cual, al igual que antes hacía Bernardino con su padre, actúa como testigo de los traslados. Efectivamente, Íñigo, heredero de la tradición familiar, está aprendiendo el oficio de manera paulatina.

Frente a lo que ocurre con Ambrosio y Bernardino, es muy poco lo que conocemos sobre las actividades profesionales de Íñigo,

\footnotetext{
lo cual parece lógico si tenemos en cuenta las limitaciones que la ley impone a los escribanos del rey a la hora de poder desarrollar su profesión allí donde había nombrados escribanos del número. No obstante, sorprende que las pocas referencias profesionales que de él disponemos sean, precisamente, elevando a escritura pública actos que legalmente estaban fuera de sus competencias, concretamente unas escrituras de compra-venta y obligaciones de pago - efectuadas entre moriscos - incluidas en un pleito entablado entre los escribanos del rey y los del número de la ciudad ${ }^{103}$
}

Parece seguro que Íñigo no heredó el cargo de su hermano: primero, porque a Obra Sierra no le consta documentalmente tal extremo, y, segundo, porque en ese caso doña Mayor de Mendoza Xarafía no hubiera depositado los protocolos de su esposo e hijo en otra escribanía distinta a la de Íñigo.

\footnotetext{
102 Santiago, "Algunos documentos arábigo granadinos", docs. 1 y 2.

103 Obra Sierra, "Aproximación", 136.
} 


\section{Estudio traductológico de los documentos editados}

\section{Dificultades}

No son pocas las dificultades que se nos presentan al abordar el estudio traductológico de los romanceamientos fehacientes del siglo XVI, y los dos documentos con que ilustramos nuestro trabajo no son una excepción.

Por un lado, prácticamente en ningún caso disponemos de los originales árabes, salvo cuando se trata de romanceamientos en el ámbito de las relaciones internacionales, lo que escapa a nuestro objetivo principal en este trabajo. Aun cuando no nos resulte difícil reconstruir los originales -al menos sus elementos más repetidos, como se podrá comprobar en el apartado posterior relativo a la evolución de las equivalencias de traducción - a la vista de las escrituras granadinas en árabe editadas, y de la experiencia acumulada en la traducción y estudio de este tipo de textos, tal ausencia supone un obstáculo metodológico importante, mas no insalvable ${ }^{104}$.

A ello se suma el gran inconveniente que supone describir, estudiar y comparar traducciones a partir de ediciones de los traslados realizadas —como hemos visto - con otros fines. Ediciones que, en no pocas ocasiones, son parciales y en las que se han suprimido todas las leyendas de traductor $u$ obviado el contexto documental en el que se describen las circunstancias que han dado lugar a los romanceamientos. Sin olvidar el desconcierto que nos provoca la lectura de ediciones de textos en los que el traslado ha sido seccionado en distintas partes y publicado en orden cronológico, rompiendo la lógica interna del expediente en el que se insertaban y dislocando la coherencia del texto ${ }^{105}$. Además, las ediciones de un mismo texto elaboradas por investigadores diferentes demuestran las vacilaciones - acaso insalvables- en las transcripciones de estos documentos ${ }^{106}$.

104 Como señala Peña, S., "El traductor en su jaula", 20, valorando el acierto de la aportación de los trabajos del traductólogo G. Toury, «los estudios descriptivos de traducciones pueden desarrollarse aun en ausencia (incluso por inexistencia) de los originales».

${ }_{105}$ Para este último caso véase, a modo de ejemplo, Espinar, "Escrituras árabes romanceadas" y "Escrituras árabes inéditas". De todos modos, hay que felicitarse también por la existencia de ediciones ejemplares como las de Malpica y Trillo, "Los infantes de Granada".

106 Sobre este particular llaman la atención las lecturas divergentes en algunos fragmentos del mismo documento realizadas por Espinar, "Escrituras árabes romanceadas", 
A todo ello debemos añadir que no disponemos siempre de ejemplos de traducciones de un mismo tipo textual (actas de compraventa, por poner un caso) realizadas por todos o la mayor parte de los traductores fehacientes del momento, exceptuando el caso de Juan Rodríguez, del que prácticamente se han editado hasta el momento romanceamientos de casi todo tipo de documentos. De todos modos, y aun cuando podamos tomar como punto de referencia para el estudio comparado varios traslados de mano distinta correspondientes a un mismo y único tipo textual, resulta mucho más difícil que las fechas de los romanceamientos nos permitan establecer el modo en que los patrones de traducción del árabe al castellano evolucionaban en este momento crucial.

Con todo, es posible sacar algunas conclusiones provisionales, que son las que exponemos en las páginas que siguen.

\section{Romanceamientos comparados y ámbito cronológico}

Hemos adoptado dos criterios fundamentales a la hora de elegir los textos a comparar de entre el conjunto ya numeroso de romanceamientos granadinos editados. Primero, por razones obvias, romanceamientos próximos cronológicamente a los dos editados. Segundo, era preciso también tomar un punto de referencia de fecha más avanzada en el siglo XVI a fin de establecer la posible evolución de los modos de traducir fehacientes en ese período fundamental de la historia de la traducción del árabe al castellano. Para esto último, hemos elegido los romanceamientos de instrumentos notariales de Alonso del Castillo, traductor de cuya trascendencia no cabe la menor duda ${ }^{107}$. Y tercero, y finalmente, el modo de traducir fehaciente del árabe en la actuali-

docs. 1, 2 y 3 y Álvarez de Morales y Jiménez, "Pleitos de agua en Granada", docs. 4.1, $4.3,4.4$, así como las supresiones de partes del expediente hechas por unos y otros investigadores.

${ }_{107}$ Desgraciadamente, no disponemos de traducciones de instrumentos notariales realizadas por Diego de Urrea, otra gran «estrella» del momento en el ámbito de la traducción. En torno a la biografia de Diego de Urrea, véase Rodríguez Mediano, F. y García-Arenal, M., "Diego de Urrea y algún traductor más: en torno a las versiones de los Plomos", Al-Qantara, XXIII (2002), 2, 499-516, y Rodríguez Mediano, F., "Diego de Urrea en Italia", Al-Qanțara XXV (2004), 183-202. Para algunas traducciones suyas del ámbito diplomático, véase García-Arenal M., Rodríguez Mediano, F. y El Hour, R., Cartas marruecas. Documentos de Marruecos en Archivos Españoles (siglos XVI-XVI), Madrid, 2002. 
dad, lo que se justifica, por un lado, si tenemos en cuenta que el origen de este modo de traducir actual se encuentra, justamente, en el periodo aquí contemplado, $\mathrm{y}$, por otro, que desde la perspectiva de los estudios de traducción — que es, no lo olvidemos, de la que parte este trabajo- los romanceamientos del siglo XVI y las traducciones juradas del siglo XX conforman un objeto unitario y homogéneo.

En resumidas cuentas, y en orden cronológico, los romanceamientos comparados con los textos aquí editados son los siguientes:

- Yuça el Mudéjar y Abrahen Alcayçi, romanceamientos de $1494^{108}$.

- Alfaquí Xarafí, romanceamiento de $1496{ }^{109}$.

- Ambrosio Xarafí, romanceamiento de $1502{ }^{110}$.

- Ambrosio Xarafí, Miguel León y Alonso Venegas, romanceamientos de $1506^{111}$.

- Fernando de Sosa, romanceamientos de $1509^{112}$

- Bernardino Xarafí, varios romanceamientos de entre 1514 y 1515, y romanceamiento de $1517^{113}$.

- Juan Rodríguez, diversos romanceamientos realizados entre los años 1524 y $1537^{114}$.

- Alonso del Castillo, dos romanceamientos de $15599^{115}$.

La traducción verbo ad verbum y la traducción-resumen de contenidos

En general, e independientemente del lugar de ejecución, las traducciones fehacientes de los siglos XV y XVI muestran dos modos de

108 Mesa Soria, "La venta de bienes de la casa Real".

109 López de Coca, La tierra de Málaga, 596-597, doc. 95.

110 Garrido Atienza, Los Alquézares de Santafé.

111 Malpica y Trillo, "Los infantes de Granada".

112 Osorio y Peinado, "Escrituras romanceadas del Convento de Santa Cruz la Real".

113 Santiago, "Algunos documentos arábigo granadinos"; Álvarez de Morales y Jiménez, "Pleitos de agua en Granada".

114 Álvarez de Morales y Jiménez, "Pleitos de agua en Granada"; Espinar, "Escrituras árabes romanceadas"; Osorio y Santiago, Documentos arábigo granadinos romanceados.

115 Espinar, "Escrituras árabes inéditas". 
operar perfectamente diferenciados: la traducción verbo ad verbum y la traducción-resumen de contenidos ${ }^{116}$.

La forma de traducción verbo ad verbum, según la expresión utilizada por varios de los romanceadores de la época ${ }^{117}$, o literal, como diríamos hoy, se identifica comúnmente - siempre en el ámbito de la traducción fehaciente - con la utilizada para trasladar los textos redactados por fedatario público musulmán bajo la égida del Estado islámico y que, debiendo hacer prueba también ante el nuevo Estado imperante, son traducidos fehacientemente a fin de ser remitidos y protocolizados ante notario cristiano o trasladados a los tribunales seculares. En algunos casos, se identifica también con el modo seguido al trasladar escrituras levantadas en lengua árabe ante escribanos públicos de arábigo tras la conquista castellana ${ }^{118}$.

La traducción-resumen de contenidos, por su parte, se identifica principalmente con los traslados destinados a los Tribunales de la Santa Inquisición ${ }^{119}$. Para el Inquisidor, traducir literalmente los documentos árabes requisados no resultaba práctico; es más, resultaba de todo punto improcedente. Lo que interesaba en este caso era resumir su contenido entresacando aquellos puntos de interés para la acusación.

El modo de proceder de Bernardino Xarafí en los romanceamientos objeto de nuestro estudio - dos escrituras notariales - es, por tanto, el común a todos sus contemporáneos: una traducción verbo ad verbum.

\footnotetext{
116 Feria, La traducción fehaciente, 148-149. Insistimos en que tratamos aquí de la traducción fehaciente, y no de ningún otro tipo. De hecho, efectivamente, la traducción verbo ad verbum también se utilizó en ocasiones en la traducción del texto coránico.

117 Respecto a este concepto en el ámbito de las traducciones cristianas y su relación con la traducción de la Biblia, véase Morreale, M., "Apuntes para la historia de la traducción en la Edad Media", Revista de Literatura, 29/30 (1959), 10. Se trata de la misma fórmula utilizada a la sazón por los escribanos, tanto seculares como eclesiásticos, cuando trasladan un documento o transcriben una deposición.

118 Como podemos ver ilustrado en algunas de las actas editadas por Espinar, "Escrituras árabes romanceadas".

119 En general, para la actuación de traductores e intérpretes de árabe en la Inquisición valenciana, véase Labarta Gómez, A., "Notas sobre algunos traductores de árabe en la Inquisición valenciana", Revista del Instituto Egipcio de Estudios Islámicos, 21 (1982), 101-33.
} 


\section{Leyenda del traductor}

Como podemos comprobar a la vista de los romanceamientos editados, son muchos los puntos en común entre el modo de proceder de los traductores fehacientes del siglo XVI y el de los traductores jurados actuales. Algunas de estas coincidencias saltan a la vista. Otras no son tan fácilmente perceptibles para el traductor actual.

Entre las coincidencias evidentes destacan las fórmulas con las que principia y concluye la traducción, similares a las utilizadas por todos los traductores de la época y muy parecidas a las actuales en su contenido básico (naturalmente, debemos salvar las distancias introducidas por la evolución lingüística). No obstante, observamos desde el siglo XVI hasta la actualidad una clara tendencia hacia la concisión. Así, Bernardino Xarafí comienza los romanceamientos que editamos con la fórmula:

Este es traslado bien e fielmente sacado de una carta de vendida escrita en papel en letra araviga firmada de dos alfaquies escrivanos publicos segund por ella paresçia la qual tornada en lengua castellana dize en esta guysa

lo que actualmente hubiera quedado en: «TRADUCCIÓN JURADA (De un contrato original de compra-venta, del árabe)», o se habría comenzado con el cuerpo de la traducción directamente.

El mismo traslado, por otra parte, termina con la siguiente leyenda:

Fecho e sacado fue este dicho traslado de la dicha carta de vendida de arávigo original en la muy noble nombrada e grand çibdad de Granada a treinta dias del mes de diziembre año del nasçimiento de nuestro Salvador Ihesuchristo de mil e quinientos e diez e siete años [...] E yo Bernaldino Xarafi escribano de la Reyna e del Rey su fijo nuestros señores, escrivano publico del número de dicha çibdad de Granada e su tierra presente fui en uno con los dichos testigos al leer e conçertar este dicho traslado con la dicha carta de vendida de arávigo original la qual señale e esto fize escribir e por ende fize aqui este mio signo (rúbrica) en testimonio de verdad. Bno Xarafi. Escrivano publico

lo que hoy quedaría, por imperativo legal, como sigue: «Yo, Bernardino Xarafí, Intérprete Jurado de Lengua Árabe, certifico que la presente es traducción fiel y completa del documento en árabe a mi presentado». 
En cualquier caso, el modo de proceder de Xarafi es en este sentido, una vez más, el común a todos sus contemporáneos.

\section{Identificación de las escrituras originales}

Como podemos observar en los dos documentos editados, Bernardino Xarafí afirma en la leyenda de traductor que «señaló» las cartas de vendida originales, esto es, las firmó, permitiendo con ello identificar los originales que estuvieron a su vista y en base a los cuales realiza el romanceamiento ${ }^{120}$. Es curioso comprobar cómo Xarafí procede también en este punto del mismo modo que lo haría un traductor jurado actual.

Xarafí no es el único que actúa así. Pese a que la mayor parte de los originales árabes de estas traducciones se han extraviado, González Palencia, al editar ciertos documentos nazaríes ${ }^{121}$, señala que están firmados por Juan Rodríguez, quien los romanceó entre los años 1537 y 1549 (ojalá lleguen a aparecer algún día los romanceamientos). Y disponemos aún de más pruebas de este modo de proceder ${ }^{122}$. Podemos colegir, pues, que también este modo de actuación era común a todos los contemporáneos de Xarafí.

\section{Conversión de fechas}

Una habilidad imprescindible para todo romanceador de la época era la capacidad para convertir las fechas de la hégira al calendario gregoriano. Se trata de una habilidad técnica que mantuvo su importancia hasta mediados del siglo XX y que hoy prácticamente ha caído en desuso: primero, porque la documentación jurídico-administrativa de los países árabes suele - excepto casos contados, como el de la documentación saudí - aportar fecha de la hégira y fecha gregoriana;

\footnotetext{
120 Aunque las actas árabes que acompañaban este expediente se encuentran en mal estado de conservación, no se aprecia en principio que el romanceador las haya "señalado», una prueba más quizás de su nula conexión con los romanceamientos editados.

${ }_{121}$ González Palencia, "Documentos árabes del Cenete".

${ }^{122}$ Cfr. por ejemplo, la lámina II en Malpica Cuello, A. y Rodríguez Lozano, J. A., "La alquería de Cázulas y la tierra de Almuñécar a finales del siglo XV (Notas y documentos para su estudio)", Estudios de Historia y Arqueología Medievales, 2 (1982), 71-89, donde aparece la firma de Juan Rodríguez.
} 
y segundo, porque hoy existen medios técnicos en la red que hacen innecesaria una habilidad tal.

No obstante, los mejores traductores de árabe demostraban a la sazón no dominar esta técnica. Este es un punto en el que las alteraciones no tienen nada de hipotéticas ni de proteicas. Así, y por sólo poner algún ejemplo de romanceador de cuya pericia no cabe dudar, Alonso del Castillo yerra en seis años en la conversión que obra en su traducción de diecisiete de enero de 1559 , y en siete, en la fechada el diecisiete de marzo del mismo año ${ }^{123}$. Y, por si fuera poco, en la traducción de un estandarte musulmán antiguo llevada a cabo en el año 1582 , se equivoca en la conversión de fechas en unos veinte años ${ }^{124}$. También Alonso de Herrera yerra en diez años en la conversión de fechas del acta que traduce el treinta y uno de diciembre de $1508{ }^{125}$.

Bernardino Xarafí fue también en esto similar a sus colegas. En las actas que editamos acierta en este punto, aunque sólo convierte el año: gran virtud en un traductor saber esquivar con disimulo. Efectivamente, el trece de safar del año 905 de la hégira corresponde al día diecinueve de septiembre de 1499 y el once de rabi I del año 905, al dieciséis de octubre 1499. Sin embargo, no muestra la misma pericia en los traslados editados por Espinar y Quesada ${ }^{126}$.

\section{La asistencia de escribiente y testigos}

El acto de la traducción fehaciente era considerado solemne en el siglo XVI, de igual modo que lo era, y sigue siendo, el del levantamiento de una escritura ante notario. En la actualidad únicamente se mantiene la solemnidad formal en la interpretación o traducción a la vista realizada por fedatario público en traducción en el acto de una vista oral o en una comparecencia ante notario. Y ello, no por el acto mismo de la traducción, sino en virtud de que dichos actos son solemnes en sí mismos. Así pues, hoy no es preciso en modo alguno que el acto de traducir sea llevado a cabo por el traductor jurado de manera

\footnotetext{
123 Espinar, "Escrituras árabes inéditas".

124 Cabanelas, El morisco granadino, 163. Esto a Cabanelas le parece «cosa un poco sorprendente, puesto que en la reducción de fechas Alonso del Castillo suele acercarse bastante a la realidad». Esta afirmación, pues, debe tomarse con precaución.

125 Espinar, "Escrituras árabes inéditas", 352.

126 Espinar y Quesada, "El regadío en el distrito".
} 
solemne y ante la presencia de testigos o de notario o secretario judicial. En todo caso, se exigirá al traductor ratificar la prueba en el acto del juicio, si fuere el caso.

En el siglo XVI, sin embargo, no cabía acto de traducción fehaciente que no reuniera todas las formalidades comunes al acto de levantar escritura pública ante notario. Esto explica el que obligatoriamente debieran asistir un mínimo de dos testigos en unidad de acto al momento de romanzar, que era también lo obligado al levantar escrituras originales. Como era costumbre en Castilla, también en Granada solían compartir tienda de escribanía dos escribanos del número, que se apoyaban mutuamente. Los meros escribientes, varios por cada tienda, desempeñaban tales funciones a veces durante años, lo que permite entender por qué los protocolos se deben a una misma mano durante períodos muy largos, $\mathrm{y}$, también, la confianza que se depositaba en ellos haciéndoles desempeñar labor de testigos o apoderados de los actuantes ${ }^{127}$.

Que este requisito resultaba imprescindible en las escribanías es asunto del que no cabe la menor duda. Empero, cabe preguntarnos hasta qué punto lo era también para la validez de los romanceamientos levantados por escribano público y si las funciones de los testigos en estos casos eran exactamente las mismas que si se tratara del levantamiento de una escritura común. La respuesta a la primera de estas cuestiones es clara: si se incumplía dicho requisito, la traducción podía ser invalidada. Entre los diversos ejemplos que lo prueban tomaremos el siguiente: Como es sabido, tras la conquista se plantearon un gran número de pleitos relativos a los límites de jurisdicción de los diferentes concejos municipales a raíz de los intereses ventilados en los repartimientos. En general, se trató de mantener la situación existente durante el período nazarí. Por ello, la documentación árabe romanceada resultaba crucial. El ejemplo al que nos referimos se enmarca en esta interminable serie de conflictos, concretamente en el que enfrentó a las localidades de Málaga y Ronda respecto a la jurisdicción sobre la Sierra de las Nieves. El máximo argumento del concejo malagueño fue entonces,

\footnotetext{
un viejo documento árabe, traducido posteriormente, $\mathrm{y}$ al que Ronda se niega a reconocer validez alguna, afirmando que se trata de una traducción efectuada sin es-

127 Obra Sierra, “Aproximación”, 146.
} 
tar presentes vecinos de la capital serrana y que, además, en dicho documento no se especifica para qué se hizo el apeamiento en él contenido, si participaron en el mismo moros de Ronda y si se hizo a solicitud suya y con su consentimiento ${ }^{128}$.

De la cita parece desprenderse la necesidad de la presencia de testigos en el acto de romanzar, por una parte, y por otra, que éstos podían tener una función de control del romanceador.

No obstante, lo cierto es que en ocasiones no parece nada claro cuál es la causa de esta exigencia y las funciones de los testigos. Es posible, puesto que los traductores no siempre disfrutaban de un nombramiento que les permitiera otorgar fe pública incontrovertible, que la razón de la presencia de la otra parte, los testigos y el escribano estuviera destinada en este supuesto a ejercer un control efectivo del buen hacer del traductor. Cuando la otra parte estaba presente, es de suponer que iría acompañada de perito, o que los mismos testigos conocían la lengua árabe. En un romanceamiento de Juan Rodríguez fechado en 1536, por ejemplo, se afirma que «los que lo corrigieron con su original e los hallaron conformes eçebto algunas partes que en el original se avian despintado e quedan aqui en blanco segund sera dicho» ${ }^{129}$. A veces, incluso, testigo y romanceador coinciden. Así, en un acta de venta fechada en Motril el 9 de junio de 1498, actúa «Francisco de Almuñécar, lengua y testigo» ${ }^{130}$, aunque, a continuación, aparecen otros dos testigos más, aparte del escribano.

En otros muchos casos sabemos que el testigo en el acto de la traducción es una autoridad de moros - reconocida, en época mudéjar, o no reconocida, en época morisca- con conocimientos de árabe y derecho islámico; aunque no siempre con conocimientos de castellano. Así, en un romanceamiento firmado por el alfaquí Xarafí -Ambrosio, si estamos en lo cierto- leemos lo siguiente:

Lo qual todo mirado y deslindado por el noble y virtuoso y sabio Çidi Mahomad el Pequenni, mandó all alfaquí Xarafí que delante del leyese e fizole leer todo el aravigo susodicho e lo romançase, y si en algo de su sentençia duda oviese, la sennalase. E todo ansi por mi el dicho alfaqui Xarafi, fue todo por verdad sacado en testigo de lo qual firmo aqui en mi nombre de la de aravigo robliqué desta rubrica. Va tachado «al prado». Vala ${ }^{131}$.

${ }^{128}$ López de Coca, La tierra de Málaga, 189-190.

129 Espinar, "El reparto de las aguas", 252.

130 Porras Arboledas, "Documentos sobre musulmanes y judíos", 138

131 López de Coca, La tierra de Málaga, 596-597. 
Por el tenor de la leyenda se advierte que el El Pequeñí, Alcadí Mayor de los mudéjares granadinos bien conocido, impuso un control estricto al traductor en lo que a su dominio del árabe se refiere, pero no podía trasladar ese control al texto romanceado. En cualquier caso, parece más que probable que la exigencia de testigos es una transposición al mundo de la traducción de los usos comunes en las escribanías.

De igual modo podemos interpretar la presencia de un escribiente en el acto formal de la traducción como un reflejo de los modos de operar en las escribanías públicas de la época. Recordemos que Bernardino Xarafí afirma en los dos documentos objeto de estudio «romançé e la fize escribir». Así pues, él traduce de viva voz y otro transcribe la traducción, lo que debía ser muy común, como en el caso de los notarios en funciones propiamente notariales. Esto responde, no cabe duda, a una tradición bien asentada desde la Edad Media: los trabajos de Canellas y Trenchs ${ }^{132}$, por ejemplo, muestran hasta qué punto notarios, traductores, simples escribanos o iluminadores eran asimilados durante los siglos XIV y XV a un mismo grupo de profesionales unidos en la palabra escrita. Los estudios sobre la antigua Escuela de Traductores de Toledo, numerosos y bien conocidos, son también significativos sobre este particular.

En general, para terminar con este apartado, debemos indicar que la identificación de los testigos que acompañan a los romanceadores, o en general a los escribanos moriscos de la época, asunto que no ha sido estudiado hasta el momento, nos puede ofrecer en el futuro no pocas sorpresas y sabrosos frutos. Antes nos referíamos a los testigos comparecientes en los romanceamientos aquí editados y cómo su identificación nos permite profundizar un poco más en el funcionamiento de las escribanías de la época. Pero veamos otro ejemplo.

Decíamos antes que las últimas actuaciones conocidas de Bernardino Xarafí como romanceador se remontan al 5 de mayo de 1518 , concretamente a la traducción de varios documentos relativos al reparto de aguas del río de la Ragüa ${ }^{133}$. Decíamos también que en aque-

132 Canellas, A. y Trenchs, J., Cancillería y cultura. La cultura de los escribanos y notarios de la Corona de Aragón (1344-1479), Folia Stuttgartensia, Zaragoza, 1988.

${ }^{133}$ Espinar Moreno, M. y M. D. Quesada Gómez, "El regadío en el distrito del Castillo de Sant Aflay. Repartimento del río de la Ragüa (1304-1524)", Estudios de Historia y Arqueología Medievales, 5-6 (1985-1986), 127-158. 
lla ocasión le asistieron como testigos Miguel de León, Francisco Jiménez y Juan de Velasco Albarracín, este último testigo en traslados de Juan Rodríguez a lo largo de muchos años ${ }^{134}$. Estos datos, que en principio no nos dicen nada, adoptan relieves cuando identificamos a dichos testigos. Juan Velasco Albarracín ha sido identificado ${ }^{135}$ como Ali Albarrazi, morisco de buena familia y reputación que actuó como testigo en las probanzas de los Infantes de Granada cuando contaba treinta y tres años de edad y que, pese a haber necesitado de intérprete en aquella ocasión, como vemos, acabó siendo oficial de varios escribanos. No cabe pensar, por tanto, que su función estuviera relacionada con su dominio de la lengua castellana. Por otra parte, a la vista de un memorial de la época relativo a los alfaquíes granadinos de la etapa mudéjar ${ }^{136}$ podemos deducir que, si se trata del mismo Juan de Velasco, como todo parece indicar, estamos ante quien con anterioridad a su conversión ejercía de alfaquí, almojarife y lector coránico - junto con otros seis alfaquíes - en la Mezquita Mayor de Granada, por todo lo cual cobraba veintiún pesantes en época nazarí, estipendios que perdió en breve. Más compleja es la identificación de Francisco Jiménez. Aunque son numerosos los moriscos que adoptaron dicho nombre, el que aquí nos interesa podría ser cualquiera de los dos alfaquíes homónimos citados en el memorial, antes conocidos como Mahoma Aben Cos y Mahoma Alayçar. Bien pudiera ser el segundo de ellos, pues en época nazarí era escribano y notario también en la Mezquita Mayor. Por último, Miguel de León, quien ya aparecido anteriormente actuando como romanceador, resulta ser también un antiguo alfaquí granadino. Imaginemos la escena: ¡un escribano público

\footnotetext{
134 A modo de ejemplo, véase la siguiente leyenda: «Lo qual yo el dicho Juan Rodriguez, escrivano e romançador suso dicho, romançe en la manera que dicha es [...]. E lo corregi e conçerte con el dicho original en la dicha çibdad de Granada a honze dias del mes de abril del dicho año de mill e quinientos e treynta e seys años. Al corregir e conçertar lo qual faser conçertar por testigos Juan de Velasco Albarrazin e Fernand Rodriguez e Gonçalo de las Nieves, veçinos desta dicha çibdad de Granada. E yo el dicho Juan Rodriguez, escrivano, romançador de las escripturas arabigas en esta dicha çibdad de Granada e su reyno por su magestad, romançe la escriptura de suso que va escripta en estas syete hojas de papel, e presente fui con los dichos testigos al corregir e conçertar con el dicho original que va firmado de mi nonbre. E fize aqui ese sygno en testimonio de verdad. Juan Rodriguez, escribano» (Espinar Moreno, "El reparto de las aguas").

${ }_{135}$ López de Coca, "Granada en el siglo XV".

136 Albarracín Navarro, J., "Memorial a propósito de los alfaquíes de la Granada mudéjar", Del Moral, C. (ed.), En el epílogo del islam andalusí: la Granada del siglo XV, Granada: Universidad, 2002, 283-306.
} 
castellano, alfaquí y descendiente de alfaquíes, asistido por tres antiguos alfaquíes de la Mezquita Mayor de Granada, uno de ellos, además, escribano en época nazarí!

\section{Letra arábiga vertida a letra de cristianos}

Apuntábamos antes que, entre los aspectos comunes en la forma de proceder de Xarafí y del resto de los traductores de la época, los hay que resultan evidentes para el hombre de hoy y otros que no lo son tanto. Entre los evidentes, en síntesis, hemos visto las leyendas de traductor, la identificación del original, las conversiones de fechas y la presencia de testigos. Resta un aspecto común al modo de proceder de sus contemporáneos que no ha sido advertido hasta hace poco, probablemente por lo natural que nos parece en la actualidad. Nos referimos al hecho de traducir del árabe al castellano utilizando en la versión de llegada la grafía latina.

Este asunto ha sido ya tratado con cierta extensión ${ }^{137}$, y por ello no vamos a entrar en detalles. Simplemente apuntaremos que, hasta la expulsión de los moriscos, la traducción fehaciente del árabe, ya fuere verbo ad verbum o resumen de contenidos, siempre utilizó grafia latina. $\mathrm{Y}$ ello en virtud de las exigencias del destinatario de la traducción, que, por definición, era una autoridad cristiana. Es en este caso en el que realmente podemos hablar de «romancear». Por el contrario, en la línea de traducción islámica del árabe al castellano, es decir, en la traducción de textos jurídico-religiosos para uso de la propia aljama de moros, resultaba prácticamente una exigencia formal la utilización de la grafia árabe, dando lugar a lo que conocemos como «textos aljamiados». En este caso, más que de romancear, debemos hablar de «aljamiar».

Bernardino Xarafí sigue también en este punto trascendental el modo de proceder común entre sus contemporáneos.

\section{Diferencias entre romanceadores y evolución}

Las traducciones de Bernardino Xarafí aquí editadas, en resumidas cuentas, podrían haber sido firmadas sin grandes diferencias por

${ }^{137}$ Feria García, M. C., "Los moriscos y el uso de la aljamía". 
cualquiera de los otros traductores del primer tercio del XVI, a excepción de Fernando de Sosa, como veremos a continuación. El romanceamiento, por tanto, equivaldría a la plantilla básica (mental, claro, no informática, como es común hoy) para este tipo de documentos que podría usar en su trabajo cotidiano Ambrosio Xarafí, Bernardino Xarafí, Juan Rodríguez, o incluso el más tardío Alonso del Castillo. Sus traducciones presentan grandes similitudes en cuanto a las opciones de traducción elegidas para cada una de las partes fijas en las que se dividen este tipo de documentos de compraventa (identificación de las partes actuantes, descripción de la finca, precio, fórmula de pago, aceptación de las partes, etc.), así como para las fórmulas-leyendas del traslado, tanto iniciales como finales. Su modo general de enfocar la traducción, verbo ad verbum y en letra castellana, sigue estos mismos modelos comunes.

Las razones que explican estas similitudes son, en síntesis, las mismas que podrían apuntarse para los traductores jurados de árabe actuales. Primero, que los traductores aprenden el oficio de otros traductores, anteriores o contemporáneos. Y segundo, que la instancia receptora tenía -y tiene- definidas unas expectativas respecto a los traslados que para el traductor es mejor, en principio, respetar.

No obstante, dentro de este modelo común, se aprecian algunas diferencias entre los romanceadores, en especial en opciones que afectan a aspectos retóricos y elementos culturales islámicos, mostrándonos con ello el modo en que la traducción fehaciente del árabe evolucionaba a lo largo del siglo XVI. Expondremos a continuación varios ejemplos significativos de esta evolución. Concretamente, el modo de traducir la basmala y la hamdala, la forma de describir las lindes, la traducción de los títulos honoríficos y epítetos de personas y nombres de lugar, la forma de traducir las fórmulas religiosas aplicadas a personas o lugares y, por último, la mención de que el acto jurídico es conforme a la ley islámica. Como decíamos al comienzo de este trabajo, ninguno de los originales árabes de los romanceamientos que a continuación analizamos se ha conservado; no obstante, a la vista de los textos traducidos y de los modelos originales conservados que no fueron nunca - que sepamos- objeto de romanceamiento, no resulta difícil establecer las equivalencias en este tipo de elementos. 
Basmala/hamdala

\begin{tabular}{|l|l|l|}
\hline 1494 & Yuça el Mudéjar & $\begin{array}{l}\text { En el nombre de Dios (padre) } \\
\text { piadoso apiadador } \\
\text { Loado (sea) Dios }\end{array}$ \\
\hline 1496 & Alfaquí Xarafí & $\begin{array}{l}\text { En el nombre de Dios, el piadoso } \\
\text { de la piedad }\end{array}$ \\
\hline 1502 & Ambrosio Xarafí & $\begin{array}{l}\text { Con el nombre de Dios, nuestro, } \\
\text { piadoso, por su misericordia } \\
\text { Las loanças (sean) a Dios }\end{array}$ \\
\hline 1506 & $\begin{array}{l}\text { Ambrosio Xarafí y } \\
\text { otros }\end{array}$ & $\begin{array}{l}\text { Con/En el nombre de Dios, pia- } \\
\text { doso, misericordioso } \\
\text { En el nombre de Dios piadoso } \\
\text { por su misericordia }\end{array}$ \\
\hline $1514-17$ & Bernardino Xarafí & $\begin{array}{l}\text { Con el nombre de Dios, Piadoso } \\
\text { e Misericordioso } \\
\text { Las/los loores a Dios }\end{array}$ \\
\hline 1532 & Juan Rodríguez & $\begin{array}{l}\text { Con/en el nombre de Dios, pia- } \\
\text { doso e misericordioso } \\
\text { Los loores a Dios }\end{array}$ \\
\hline 1559 & Alonso del Castillo & $\begin{array}{l}\text { Con el nombre de Dios, piadoso } \\
\text { y misericordioso }\end{array}$ \\
\hline
\end{tabular}

A propósito de la basmala, téngase en cuenta que la fórmula elegida comúnmente por los traductores de las versiones aljamiadas del Corán durante los siglos XV y XVI es «En el nombre de Allah piadoso de piedad» ${ }^{138}$.

138 Cfr. por ejemplo las ediciones de Vernet, J. y López Lillo, C., "Un manuscrito morisco del Corán", Boletín de la Real Academia de Buenas Letras de Barcelona, 35 (1973-1974), 188-255; Alcorán: Traducción castellana de un morisco anónimo del año 1606, introducción de J. Vernet Ginés, transcripción de L. Roqué Figuls, Barcelona: UNED - Reial Acadèmia de Bones Lletres, 2001. Para más detalles sobre esta fórmula, Feria García, M. C. y Peña, S., "De un maestro morisco", El trujamán, Revista Digital del Instituto Cervantes, 31 de agosto de 2000. 
Mención de nombres propios

\begin{tabular}{|l|l|l|}
\hline 1494 & Yuça el Mudéjar & $\begin{array}{l}\text { Guadix, guardele Dios } \\
\text { El alcayde, alargue Dios su estado }\end{array}$ \\
\hline 1496 & Alfaquí Xarafí & $\begin{array}{l}\text { Málaga, guárdela Dios; Granada, } \\
\text { que Dios guarde } \\
\text { Abulhafix... sostenga Dios su hon- } \\
\text { ra... que Dios perdone }\end{array}$ \\
\hline 1502 & Ambrosio Xarafí & $\begin{array}{l}\text { Granada, que Dios guarde; que } \\
\text { Dios prospere } \\
\text { Hamete... que Dios honre... que } \\
\text { Dios conforme }\end{array}$ \\
\hline 1506 & $\begin{array}{l}\text { Ambrosio Xarafí y } \\
\text { otros }\end{array}$ & $\begin{array}{l}\text { Granada, la alta, que Dios altísi- } \\
\text { mo goarde } \\
\text { Çoraya, goarde Dios su persona y } \\
\text { estado }\end{array}$ \\
\hline $1514-17$ & Bernardino Xarafí & (Sin fórmulas) \\
\hline 1532 & Juan Rodríguez & $\begin{array}{l}\text { Mahamad... que Dios conserve y } \\
\text { guarde su estado... } \\
\text { (difunto)... perdónelo Dios... que } \\
\text { sea en gloria }\end{array}$ \\
\hline 1559 & Alonso del Castillo & (sin fórmulas) \\
\hline
\end{tabular}




\section{Linderos}

\begin{tabular}{|l|l|l|}
\hline 1494 & Yuça el Mudéjar & $\begin{array}{l}\text { El alquibla es... e del jaofy... el sa- } \\
\text { liente es... y el Garve (poniente) }\end{array}$ \\
\hline 1496 & Alfaquí Xarafí & $\begin{array}{l}\text { Que tyene por sitios de la parte } \\
\text { dell Alquibla... del çierço... de le- } \\
\text { vante... del poniente }\end{array}$ \\
\hline 1506 & $\begin{array}{l}\text { Ambrosio Xarafí y } \\
\text { otros }\end{array}$ & $\begin{array}{l}\text { Que alinda por la parte solana... } \\
\text { del çierço... de levante }\end{array}$ \\
\hline $1514-17$ & Bernardino Xarafí & $\begin{array}{l}\text { Que alinda por la parte solana... } \\
\text { del çierço... de levante... de po- } \\
\text { niente }\end{array}$ \\
\hline 1532 & Juan Rodríguez & $\begin{array}{l}\text { Que alinda por la parte del medio- } \\
\text { dia... del çierço... de levante... de } \\
\text { poniente }\end{array}$ \\
\hline 1559 & Alonso del Castillo & $\begin{array}{l}\text { Que alinda por la parte del medio- } \\
\text { dia... del çierço... de levante... de } \\
\text { poniente }\end{array}$ \\
\hline
\end{tabular}

Conforme a la ley islámica

\begin{tabular}{|l|l|l|}
\hline 1494 & Yuça el Mudéjar & Segund el çuna e costunbre dello \\
\hline 1506 & $\begin{array}{l}\text { Ambrosio Xarafí y y } \\
\text { otros }\end{array}$ & $\begin{array}{l}\text { Conforme a la costumbre de los } \\
\text { moros e a los saneamientos de las } \\
\text { leyes dellos }\end{array}$ \\
\hline $1514-17$ & Bernardino Xarafí & Por la regla e çuna de moros \\
\hline 1532 & Juan Rodríguez & Por la costumbre en ello \\
\hline 1559 & Alonso del Castillo & $\begin{array}{l}\text { Conforme a la ley y regla ques çer- } \\
\text { ca desto }\end{array}$ \\
\hline
\end{tabular}

Como podemos comprobar, la evolución general de los modos de traducir fehaciente del árabe en la época muestra una tendencia clara hacia la desislamización de las versiones. La lengua árabe va perdien- 
do poco a poco su presencia en el texto castellano, y con ella la cultura religiosa y jurídica que subyace a los originales y que tan presente se hacía en las traducciones de la línea islámica (dicho de otro modo, en los textos aljamiados). A esta tendencia, que se acentúa a medida que avanza el siglo XVI, no son ajenos los textos aquí editados, ni su artífice, ni la familia a la que éste pertenece. La tradición medieval - o mudéjar - del oficio sufre con ello una evolución acorde a las imposiciones de las instancias receptoras, lo que explica también las vacilaciones y dudas que a veces reflejan estas traducciones.

El resultado de ello perduraría - a excepción del movimiento de traducciones del árabe en las plazas de Berbería, que se mantuvo, como éstas en tantos aspectos, un poco al margen de la historia- hasta al menos finales del siglo XVIII ${ }^{139}$.

\section{Las versiones de Fernando de Sosa}

Mención aparte merecen las traducciones del citado Fernando de Sosa, cuyas versiones en castellano, a pesar de realizarse en época cercana a la de los Xarafí o Juan Rodríguez, parecen seguir otros modelos. Sirvan como primer ejemplo las siguientes fórmulas:

Con sus derechos e rentas e defendimentos, provechos, entradas e salidas...venta buena, fyrme, estable e valedera por el presçio que es su valor, a saber, por...

O sus opciones de traducción para los casos arriba mencionados:

En el nombre de Dios, piadoso, misericordioso etc./ Alabado sea Dios/ Alabado Dios

El honrado... la bendita... (supresión de otros epítetos)

Granada (sin fórmula)

Que ha por linderos por la parte del mediodía... del norte... del oriente... del oçidente

Conforme a la orden e costumbre/regla del derecho

139 Respecto al viraje que comienza a producirse en esas fechas en el mundo de la traducción del árabe, véase Feria García, M. C., Peña, S. y Vega, M., "Miguel Casiri y los cambios de actitud", El trujamán, Revista Digital del Instituto Cervantes, 24 de julio de 2002. 
Incluso para la fórmula final del traslado, más breve que el del resto aunque idéntica en función y muy similar en el contenido, sigue un patrón distinto:

\footnotetext{
Fecho e sacado fue este dicho traslado de las dichas dies e seys escripturas aráuigas, segund por ellas paresçe. El qual fue convertido en lengua castellana por mi, el dicho Fernando de Sosa, yntérprete de Sus Altesas. El qual se fizo e sacó en la çibdad de Granada, postrimero día del mes de abril año del nacimiento de nuestro Saluador Thesuchristo de mill e quinientos e seys años, e va çierto. En fee de lo qual lo fyrmé de mi nombre. Fernando de Sosa ${ }^{140}$.
}

Lo cierto es que nos hallamos ante un modo de traducir que se diría «adelantado» a su tiempo, en el sentido de que guarda mayores similitudes con las opciones de Alonso del Castillo, por ejemplo, que con las del mismo Ambrosio Xarafí. Y ello pese a que, muy probablemente, Gabriel Ysrael-Fernando de Sosa era de muy mayor edad que Ambrosio: baste con recordar la fecha de su nombramiento como Trujamán Mayor del Reino de Murcia. Por consiguiente, resulta difícil explicar estas diferencias con los traductores moriscos simplemente en virtud de una evolución cronológica natural. Antes bien, se diría que existen otros motivos para ello. Quizás, de carácter religioso o, desde otro punto de vista, puede que por ausencia del peso de la tradición trujamanesca islámica mudéjar.

\section{Conclusiones}

1. La edición y estudio de las escrituras andalusíes romanceadas, obra de arabistas e historiadores del tránsito de la Edad Media a la Moderna en la Península Ibérica, nos ha dado a conocer más de doscientos textos de notable interés.

2. No obstante, dicha labor padece claras deficiencias metodológicas derivadas, fundamentalmente, de haberse ignorado la naturaleza primaria de estos textos, que no son sino traducciones. Ello se explica si tenemos en cuenta la escasez de materiales documentales andalusíes originales conservados y la relativa modernidad de los estudios de traducción.

140 Osorio y Peinado, "Escrituras romanceadas del Convento de Santa Cruz la Real", 214. 
3. En consecuencia, y partiendo de los presupuestos establecidos en áreas de estudio tales como la Traductología y la Historia de la Traducción, llamamos la atención sobre las deficiencias que se observan en dichas ediciones y la necesidad de un mayor rigor en el estudio de las escrituras andalusíes romanceadas.

4. Por nuestra parte, proponemos en este trabajo un acercamiento a dicho corpus fundado en los presupuestos y aparato conceptual aceptados en los actuales estudios de traducción, lo que, a nuestro juicio, permitirá un mejor y más amplio aprovechamiento de dichas fuentes.

5. Este nuevo enfoque se ilustra en este trabajo con la edición y estudio de dos romanceamientos hasta ahora desconocidos llevados a cabo por Bernardino Xarafí en 1517.

6. A fin de enmarcar los dos romanceamientos editados, ofrecemos una breve panorámica de la traducción fehaciente en la Granada del siglo XVI: originales, traducciones, traductores y modos de proceder.

7. Entre los romanceadores hemos prestado especial atención a los Xarafí, familia del romanceador de los documentos aquí estudiados, de gran tradición en el oficio y una de las grandes protagonistas de la historia de la traducción del árabe al español. Desde otro punto de vista, la trayectoria profesional de los Xarafí constituye un magnífico ejemplo del perfil cultural, religioso y sociológico del colaboracionismo mudéjar y morisco entre las sagas andalusíes de alfaquíes que, integrados en oficios tales como la escribanía y la trujamanería, desempeñarán un papel trascendental en las relaciones entre cristianos nuevos de moros y autoridades castellanas.

8. Fundándonos en el cotejo de diferentes traslados de seis romanceadores granadinos de la época, así como a la vista de los procedimientos actualmente aceptados en la traducción jurada del árabe al español, hemos llevado a cabo también un análisis traductológico general de los dos romanceamientos editados.

9. En lo relativo a los procedimientos de traducción seguidos por Xarafí, dicho análisis nos ha llevado a concluir que la mayoría de los romanceadores fehacientes de la época - mudéjares y moriscostraducía de modo muy similar.

10. Concluimos también que los modos de proceder en el oficio apenas han cambiado desde finales del siglo XV hasta la actualidad, lo que indica: primero, que para esas fechas ya existía una tradición bien 
consolidada en el campo de la traducción fehaciente del árabe; y segundo, y ante todo, que es en estos traductores, y en sus precedentes inmediatos, donde se encuentran los orígenes de muchos de los modos de traducir que ya hoy pudieran antojársenos cosa inmutable o no sujeta a convención.

11. No obstante, hemos observado también discrepancias entre este modo general de proceder entre mudéjares y moriscos y el mostrado por Fernando de Sosa, cristiano nuevo de judíos. Ello nos lleva a plantear la hipótesis de que el fenómeno pudiera deberse al diferente origen étnico y religioso del traductor o, por lo mismo, a tradiciones diferentes en el oficio de la trujamanería.

12. Hemos observado también cómo a lo largo del siglo XVI se produjo una desislamización progresiva del producto de los traslados: supresión de referencias religiosas y culturales islámicas y progresiva pérdida de la presencia de la lengua árabe. Este fenómeno - en el que, como en otros puntos, también las traducciones de Fernando de Sosa resultan sorprendentemente adelantadas a su tiempo- supone una suerte de giro copernicano respecto a la tradición mudéjar en la traducción fehaciente del árabe, así como respecto a las traducciones contemporáneas de la línea islámica (en otras palabras, respecto a la literatura aljamiada no original). Esta desislamización alcanza su punto culminante a finales del XVI y se mantiene, cuando menos, hasta finales del XVIII.

13. En síntesis, con este trabajo pretendemos animar el inicio de una nueva vía de investigación que aborde el corpus documental de escrituras andalusíes romanceadas en cuanto que parte de la historia de la traducción del árabe al español, lo que, creemos demostrado, puedo ofrecer frutos novedosos y una mejor fundamentación metodológica de la investigación en este campo.

\section{RESUMEN}

Propuesta de un nuevo y complementario enfoque —el traductológicopara el estudio de los romanceamientos granadinos considerados en cuanto que testimonios únicos para la historia de la traducción del árabe al español y la historia del arabismo en España. Dicho enfoque se lleva aquí a la práctica ilustrado con dos romanceamientos inéditos llevados a cabo en 1517 por Bernardino Xarafi, escribano público y romanceador de la ciudad de Granada y su Reino. La edición de los mismos se acompaña de un amplio estudio traductológico, una 
panorámica general sobre los Xarafí y otros romanceadores granadinos del primer tercio del XVI y un análisis descriptivo comparado con otros romanceamientos del siglo XVI y con los procedimientos de traducción actualmente aceptados en la traducción jurada del árabe al español.

\begin{abstract}
A new and complementary approach to the corpus of 15th- and 16th-century translations from Arabic into Spanish is proposed, based on the assumption that this corpus can also be studied from a translatological point of view as unique evidence of the history of translation in Spain. The approach is illustrated with the edition of two 1517 translations from Arabic into Spanish by Bernardino Xarafi, a notary public and official translator of the City and Kingdom of Granada. These two formerly unedited translations are supported by a two-fold translatological study: an introduction to the Xarafi's family and to the Granadino translators from the first half of the 16th century, and a descriptive, contrastive analysis of several contemporary translations, and of official translation ways and practices currently applied.
\end{abstract}

